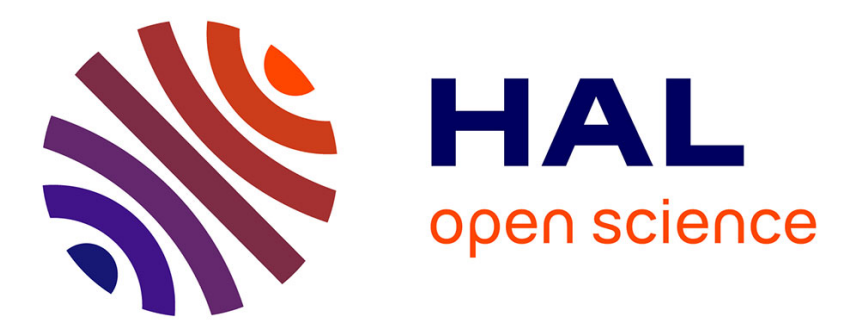

\title{
Effects of marine noise pollution on Mediterranean fishes and invertebrates: A review
}

\author{
E. Di Franco, P. Pierson, L. Di Iorio, A. Calò, J.M. Cottalorda, B. Derijard,
} A. Di Franco, A. Galvé, M. Guibbolini, J. Lebrun, et al.

\section{- To cite this version:}

E. Di Franco, P. Pierson, L. Di Iorio, A. Calò, J.M. Cottalorda, et al.. Effects of marine noise pollution on Mediterranean fishes and invertebrates: A review. Marine Pollution Bulletin, 2020, 159, pp.111450. 10.1016/j.marpolbul.2020.111450 . hal-02943059

\section{HAL Id: hal-02943059 \\ https://hal.science/hal-02943059}

Submitted on 14 Dec 2020

HAL is a multi-disciplinary open access archive for the deposit and dissemination of scientific research documents, whether they are published or not. The documents may come from teaching and research institutions in France or abroad, or from public or private research centers.
L'archive ouverte pluridisciplinaire $\mathbf{H A L}$, est destinée au dépôt et à la diffusion de documents scientifiques de niveau recherche, publiés ou non, émanant des établissements d'enseignement et de recherche français ou étrangers, des laboratoires publics ou privés. 


\section{Effects of marine noise pollution on Mediterranean fishes and invertebrates: a review}

E. Di Franco ${ }^{1}$, P. Pierson ${ }^{1}$, L. Di Iorio ${ }^{2,3}$, A. Calò ${ }^{1,4}$, J.M. Cottalorda ${ }^{1}$, B. Derijard ${ }^{1}$, A. Di Franco $^{1,5}$, A. Galvé ${ }^{6}$, M. Guibbolini ${ }^{1}$, J. Lebrun ${ }^{7}$, F. Micheli ${ }^{8}$, F. Priouzeau ${ }^{1}$, C. Risso-de

Faverney $^{1}$, F. Rossi ${ }^{1}$, C. Sabourault ${ }^{1}$, G. Spennato ${ }^{1}$, P. Verrando ${ }^{9}$, P. Guidetti ${ }^{1,10,11}$

${ }^{1}$ Université Côte d’Azur, CNRS, UMR 7035 ECOSEAS, Nice, France

${ }^{2}$ CHORUS Institute, Phelma Minatec, 38016 Grenoble, France

${ }^{3}$ Foundation of the Grenoble Institute of Technology, 38031 Grenoble, France

${ }^{4}$ Dipartimento di Scienze della Terra e del Mare (DiSTeM), Università di Palermo, Via

Archirafi 20, 90123 Palermo, Italy

${ }^{5}$ Stazione Zoologica Anton Dohrn, Dipartimento Ecologia Marina Integrata, Sede

Interdipartimentale della Sicilia, Lungomare Cristoforo Colombo (complesso Roosevelt),

4521, 90142 90149 Palermo, Italy

${ }^{6}$ Université Côte d’Azur, CNRS, Observatoire de la Côte d'Azur, IRD, Géoazur, SophiaAntipolis, France

${ }^{7}$ Université Côte d'Azur, CNRS, UMR 7271 I3S, Sophia Antipolis, France

${ }^{8}$ Hopkins Marine Station and Stanford Center for Ocean Solutions, Stanford University, Pacific Grove, CA 93950, USA

${ }^{9}$ Université Côte d’Azur, Institut de Biologie Valrose (iBV, INSERM U1091 - CNRS

UMR7277), Nice, France

${ }^{10}$ CoNISMa (Interuniversitary Consortium of Marine Sciences), Rome, Italy

${ }^{11}$ National Institute of Marine Biology, Ecology and Technology, Stazione Zoologica A.

Dohrn, Villa Comunale, 80122 Naples, Italy 
Key words: marine noise pollution, stress responses, behavioral alterations, population and ecosystem impacts, sustainable development

Highlights ( 3 to 5 bullet points, maximum 85 characters, including spaces, per bullet point, to be submitted in a separate editable file in the online submission system, using 'Highlights' in the file name).

Marine noise is a widespread source of pollution in the Mediterranean Sea

- Noise pollution produces a multitude of impacts on marine fish and invertebrates

- Marine noise pollution impacts individuals to ecosystems

- A variety of measures could be adopted to mitigate marine noise pollution

\begin{abstract}
(max 150 words):
Marine noise pollution (MNP) can cause a multitude of impacts on many organisms, but information is often scattered and general outcomes difficult to assess. We systematically reviewed the abrilable invertebrates. Both chronic and acute MNP produced by several human activities - e.g. maritime traffic, pile driving, air guns - were found to cause detectable effects on intraspecific communication, vital processes, physiology, behavioral patterns, health status and survival. These individual-based effects can extend to induce population- and ecosystem-wide alterations, especially when MNP impacts functionally important species, such as keystone predators and habitat forming species. Curbing the threats of MNP in the Mediterranean Sea is not aneasya challenging task, but a variety of measures shoult could be adopted to mitigate MNP impacts. Successful measures will require more precise-accurate information on impacts, and that effective management of MNP actually becomes a priority in the policy makers' agenda.
\end{abstract}

Funding: This work has been supported by the French government, through the UCA ${ }^{\text {JEDI }}$ Investments in the Future project managed by the National Research Agency (ANR) with the reference number ANR-15-IDEX-01. It was carried out in the framework of the "Nautilus Project”, supported by the Academy of Excellence 3 ("Space, Environment, Risk and Resilience”). 


\section{Introduction}

The marine noise generated by human activities has increased drastically since the first Industrial Revolution, especially after the second world war (Frisk, 2012). Nowadays, the ocean is reported to be 2-10 times louder compared to the pre-industrial period (Hildebrand, 2009; Frisk, 2012). This trend is likely to continue in the future due to increasing human population, coastal urbanization, maritime traffic, oil extraction and other ocean-based energy production systems (e.g. wind and wave farms, wave energy).

Pollution is generally defined as the direct or indirect introduction into the environment of substances or energy (MSDF; EU, 2008) resulting from anthropogenic activities potentially threatening living resources and ecosystems. The locution "marine noise pollution” (hereafter MNP) has been coined to define any source of anthropogenic sound occurring in the marine environment capable of producing deleterious effects on marine life (MSDF; EU, 2008). MNP is today considered as an emerging and remarkable source of pollution by national and international legislations, including the United Nations Convention on the Law of the Sea (UNCLOS; ICP-19, https://undocs.org/A/73/124) and the European Marine Strategy Framework Directive 56/2008 CE (MSFD; EU, 2008).

MNP is reported to interfere with 1) vocalizations emitted by many animals to communicate with their conspecifics e.g., for mate attraction/selection, avoiding predators or alerting about the presence of threats (Hatch et al., 2012; Erbe et al., 2016); 2) natural sounds that animals perceive and use as clues for orientation in space, movements in search of food, migration to reproductive areas, and detection of appropriate habitats for settlement (Simpson et al., 2016). MNP can thus alter behaviors and interfere with many vital processes (Erbe et al., 2016; Rako-Gospić and Picciulin, 2019), as well as cause physiological impacts ranging from mild stress to internal bleeding and ultimately death (Fernández et al., 2005; Aguilar de Soto et al., 2016; Hawkins and Popper, 2018).

Originally, studies of the impact of MNP mainly focused on physiology and behavior of marine mammals (e.g., Aguilar de Soto et al., 2016; Erbe, 2002; Nowacek et al., 2007; Wright et al., 2007; Götz and Janik, 2013; Weilgart, 2017). In the last decade, however, there has been a considerable increase in research on MNP as an important source of stress for other marine animals, like many species of fish and invertebrates capable of producing and detecting sounds (Tolimieri et al., 2000; Popper et al., 2001; Montgomery et al., 2002; Amorim, 2006; Hu et al., 2009; Patek et al., 2009; Holt and Johnston, 2011; Ladich, 2019). 
Understanding the impact of MNP on fish and invertebrates is crucial because both these groups include species that are threatened or have a significant socio-economic importance, e.g. for fisheries and aquaculture (Holmlund and Hammer, 1999; Anderson et al., 2011; Eddy et al., 2017). Also, many species of invertebrates and fish play key roles: 1) some species occupy, within food webs, a range of trophic positions from primary consumers to apex predators, in some cases as keystone predators (like some coastal fishes and lobsters; Hammerschlag et al., 2019); 2) other species contribute considerably to carbon and nitrogen cycles (Pinnegar, 2018); 3) other species, finally, are habitat-forming species, e.g. some bivalve mollusks and corals (Peirano et al., 1998; Tolley and Volety, 2005; Pitacco et al., 2017). Therefore, as many fish and invertebrates play key ecological roles contributing to shape whole communities, . Uunderstanding the possible impacts of MNP on these organisms is vital to design and adopt appropriate management, conservation and restoration measures (Slabbekoorn et al., 2010; Hawkins et al., 2014; Tidau and Briffa, 2016; Weilgart, 2018; Rako-Gospić and Picciulin, 2019).

There are two distinct types of MNP, depending on the intensity and duration: 1) acute MNP, characterized by sounds with high intensity and short duration, often emitted repeatedly and over a wide frequency band (e.g. sonar, explosions, pile driving, air guns); 2) chronic MNP, generally characterized by a lower intensity but a longer duration, to which animals are exposed regularly or over longer time lapses (e.g. boat traffic; Rako-Gospić and Picciulin, 2019). Chronic MNP is much more widespread than acute MNP and is widely considered as the main contributor to the increase in ocean background noise ( MSFD EU, 2008; Hildebrand, 2009). These different types of MNP can co-occur and interact in producing their impact on marine life.

Two components of noise may influence the relationships between sounds and living beings: 1) particle motion, i.e. the back-and-forth motion of particles in the medium; 2) sound pressure, i.e. the pressure fluctuations with zones of high and low pressure in the medium (see https://dosits.org/decision-makers/tutorials/science/what-is-sound/ for a visual representation of these two components). Fish mainly produce sounds at frequencies $<4000 \mathrm{~Hz}$ (in most cases below $1000 \mathrm{~Hz}$ ). Their hearing abilities can differ substantially depending on the species: 1) most species, called "hearing generalists", perceive the sound as particle motion; 2) other species, called "hearing specialists”, possess gas-filled cavities like the swim bladder, which resonate with sounds. This condition allows "hearing specialist” fishes to perceive both particle motion and sound pressure, covering a larger frequency band of sound. 
Hearing specialist fishes are generally more sensitive to MNP, essentially because the vibration of their gas-filled cavities in the presence of noise can lead to rupture of these cavities and cause damages to the surrounding organs (Halvorsen et al., 2012). Invertebrates do not have gas-filled cavities and are likely to just perceive the particle motion component of sound. Fish and invertebrates hearing is mostly sensitive to sounds $<2000 \mathrm{~Hz}$, which correspond to the frequency band of most anthropogenic noises (Hawkins and Popper, 2018), and are therefore likely to be sensitive to and potentially affected by MNP (being most of the energy produced by MNP <1000 Hz; Hildebrand, 2009).

The Mediterranean Sea is a temperate and semi-enclosed basin crossed by some of the most important marine trade routes (Fig. 1), where coastal areas are highly urbanized, and fishery resources heavily exploited and multiple threats concentrate making it a sea "under siege” (Micheli et al., 2013). The Mediterranean Sea is thus likely to be particularly affected by MNP, suggesting the urgent need to develop more investigations for improveing our understanding of its effects on marine life and mitigateing its ecological impacts.

The aims of this review, therefore, are: i) to synthesize the available and sparse information about the impact of MNP on Mediterranean fishes and invertebrates; ii) to identify knowledge gaps and priorities for future research guiding the design and adoption of management and mitigation measures.

\section{Materials and methods}

Google Scholar (https://scholar.google.com/) and Web of Science (https://webofknowledge.com) were used to perform a systematic search of the literature following the PRISMA review protocol (http://www.prisma-statement.org/, see Supplementary figure 1 for visual flowchart). Results were limited to peer-reviewed articles published in international journals between January 1990 and December 2019. The specific search terms were “fish” OR “invertebrate/s” AND “marine noise” OR “noise pollution” OR “anthropogenic noise” AND “behavior” OR “stress” or “physiology” AND “Mediterranean”. Additional peer-reviewed articles were identified by screening references cited in the selected primary literature.

-In the present review, we considered both field and laboratory studies because they offer different and often complementary information. Field observational studies are generally 
useful to collect correlative evidence about the effects of MNP under natural conditions. However, field investigations have the disadvantage that the multiple sources of variation (other than MNP) possibly influencing the response variables under study cannot be controlled, so that the putative effects of MNP cannot be disentangled from other sources of variation. In contrast, experiments conducted in controlled conditions (e.g. in mesocosms) allow to control other possible sources of variations. They thus allow to directly assess the effects of MNP, even though they may suffer from the bias introduced by experimental artifacts (Parvulescu, 1967; Akamatsu et al., 2002; Duncan et al., 2016; Rogers et al., 2016), while generally omitting natural complexity and variability (e.g. daily, seasonal) of a number of factors (e.g. temperature, salinity, $\mathrm{pH}$ ) possibly affecting the response variables (see Underwood, 1997 for generalities and more details about experimental logics).-

This literature search first produced 652 results, which decreased to 506 after having removed duplicates. The articles' abstracts were then reviewed to select field or in aquaria/mesocosm studies with the main focus on the effects of MNP on Mediterranean fish and/or invertebrate species (i.e. species native of the Mediterranean, whose distribution range is not necessarily limited to the basin). Forty-five studies finally met the selection criteria. These articles were then classified based on the taxonomic group, the type of noise (i.e. acute vs. chronic), the origin of the noise (e.g. ships, pile-driving), the experimental setup (i.e. field vs. mesocosms), the intensity and frequency of the noise, its duration and the location where field studies have been carried out (see Supplementary Table 1 for further details).

\section{Results and discussion}

Among the forty-five studies selected, fifteen were conducted in the field (six of them have been actually carried out in the Atlantic waters, North Sea or Baltic Sea on species living also in the Mediterranean basin, while nine have been conducted in Mediterranean waters), mostly in the west part of the Mediterranean basin and in the Adriatic Sea (Fig. 1).

The literature review showed an increasing trend in the number of studies about MNP, especially in the last decade. Specifically, up to 2004 only 2 (4\%) studies had been published on the impact of MNP on Mediterranean fishes and invertebrates, 4 (8\%) between 2005 and 2009, 15 (33\%) between 2010 and 2014 and 24 (53\%) between 2015 and 2019 (Fig. 2 A).

The analysis of the published articles highlighted that: 
1) 24 (53\%) studies focused on chronic MNP, 20 (45\%) on acute MNP and 1 (2\%) investigated both MNP types (Fig. 2 B);

2) 21 (47\%) studies investigated the effects of MNP produced by ships/vessels, 6 (13\%) by pile driving, 1 (2\%) by both, 1 (2\%) by air guns, 1 (2\%) by pingers normally used as marine mammals' deterrent and 15 (34\%) by a computer replicating one or many of the previously mentioned noise sources (Fig. 2 C);

3) $30(67 \%)$ studies were conducted on fishes and 15 (33\%) on invertebrates (8 (18\%) on crustaceans, 6 (13\%) on cephalopods and 1 (2\%) on cnidarians) (Fig. 2 D);

4) 30 (67\%) studies were conducted under controlled conditions (e.g. aquaria) and 15 (33\%) in the field, either using caged or free-living individuals (Fig. $2 \mathrm{E}$ );

5) 23 (51\%) studies assessed the impact of MNP on behavior, 14 (31\%) on physiology and 8 (18\%) on both (Fig. 2 F).

We analyzed more in depth the studies for their specific contents by classifying them based on two criteria: taxonomic group impacted (fish vs invertebrates) and MNP type (acute vs chronic). Results are reported here below.

\section{Impact of MNP on fishes}

Thirty out of the 45 studies focused on fish. Approximately half of them (13) analyzed the response of two species, the European seabass (Dicentrarchus labrax) and the gilthead seabream (Sparus aurata). These two species represent more than $90 \%$ of the European marine aquaculture production (FEAP 2016, http://feap.info/). The remaining studies dealt with flat (the common sole Solea solea, the European plaice Pleuronectes platessa), pelagic (the wild sprat Sprattus sprattus, the mackerel Scomber scombrus, the Allis shad Alosa alosa, the Atlantic bluefin tuna Thunnus thynnus), cryptobenthic (the red-mouthed goby Gobius cruentatus, the Common goby Pomatoschistus microps, the lusitanian toadfish Halobatrachus dydactilus, the long-snouted seahorse Hippocampus guttulatus) and other coastal/demersal species (the black seabream Spondyliosoma cantharus, the whiting-pout Trisopterus luscus, the thicklip grey mullet Chelon labrosus, the brown meagre Sciaena umbra, the damselfish Chromis chromis and the European eel Anguilla anguilla). See Table 1 for a summary of the response variables tested for each species. 
In Table 1 of Supplementary Material more details about the studied species, the noise features (type, level, duration and frequency) and the locations where the studies included in this review have been conducted, are reported.

\section{Acute MNP}

The available studies showed fairly heterogeneous results. Seven studies have been carried out on the potential impact of pile driving, either in the field or in controlled conditions (mesocosms or aquaria). Studies on juvenile European seabass (Debusschere et al., 2016; Radford et al., 2016), larvae of common sole (Bolle et al., 2012) and adults of European plaice (Bruintjes et al., 2016b) did not report any detectable effect from pile driving noise in terms of instantaneous or delayed mortality, long term effects on ventilation rate or oxygen uptake by organisms. Available evidence suggests that pile driving does not have any significant effect on the investigated species, development stages or variables measured. These results could be related to the experimental settings not representative of real conditions (see Akamatsu et al., 2002; Rogers et al., 2016), and/or also to a rapid recovery, an increase in tolerance or a change in hearing sensitivity, resulting in an absence of permanent/detectable effects on the measured variables. Other studies showed that juvenile and adult European seabass, and adult black seabream exposed to pile driving noise, displayed a decrease or increase of oxygen consumption rate (Bruintjes et al., 2016b; Debusschere et al., 2016), which is indicative of a stress-induced response. Pile driving has also been reported to affect the structure and dynamics of shoals of juvenile seabass that tend to be less cohesive, less directionally ordered and less coordinated in speed and directional changes (Herbert-Read et al., 2017). Hawkins et al. (2014) exposed schools of wild sprat and mackerel to sequences of acute noises simulating strikes from pile driving and showed that sprat schools were more likely to disperse and mackerel schools more likely to change swimming depth.

Significant effects of pile driving noise on oxygen consumption and grouping behavior have been mostly detected on confined individuals following exposure to the "real” pile driving noise in the natural environment (Santulli et al., 1999; Bruintjes et al., 2016a; Debusschere et al., 2016; Hawkins et al., 2014). On the contrary, the studies where no effect has been observed used playbacks records of real noises emitted either in aquaria or in the field (Bolle et al., 2012; Debusschere et al., 2014; Bruintjes et al., 2016b; Radford et al., 2016). The two exceptions reviewed here are the case of European plaice directly exposed to the real pile driving noise, where no detectable effects on oxygen consumption have been 
reported (Bruintjes et al., 2016b), and the modification of structure and dynamics of shoals of European seabass reported in aquaria (Herbert-Read et al., 2017).

Santulli et al. (1999) investigated the potential effects of another type of acute noise, the air gun acoustic waves. The authors showed a biochemical response in caged European seabass exposed to this type of stress. Such a response consisted of transient alterations of cortisol, glucose, lactate, AMP, ADP, ATP and cAMP in blood and different tissues, which went back to normality within $72 \mathrm{~h}$ post-exposure.

To test whether intermittency, amplitude fluctuation, repetition interval regularity and the presence of 'ramp-up' have the potential to impact fish behavior, Neo et al., (2014, 2015, 2016) exposed adults of European seabass to multiple types of artificial noises. They reported multiple behavioral responses including increased group cohesion, swimming speed and depth, startle response (i.e., sudden change in swimming direction and acceleration). All these behavioral changes could be due to the perception of the noise by fish, considered as a potential threat.

Effects of acute noises with higher frequency and much lower intensities compared to pile driving and air gun have also been tested. Kastelein et al. (2007) investigated, in outdoor tanks, the effects of the noise of different dolphin anti-depredation pingers on adults of three Mediterranean fish species, i.e. European seabass, Whiting-pout and thicklip grey mullet. While exposed to this noise, these fishes displayed pinger- and species-specific alterations in terms of swimming-speed and -depth. An increase in swimming speed (possibly related to an escape reaction; Wilson et al., 2008) has been observed in adults of Allis shad in response to ultrasounds (Wilson et al., 2008). This species can perceive these frequencies that correspond to the sounds produced by some of their natural predators (i.e. sea mammals), which are similar to those of sonars or boat propellers.

\section{Chronic MNP}

All the studies we have found about chronic MNP dealt with boat noise, produced by recreational or fishing vessels, ships and ferries. Thirteen studies investigated the effects of chronic noise exposure, either through playbacks in aquaria $(n=7)$ or directly in the field on wild fish $(\mathrm{n}=6)$.

Studies that employed playback records in aquaria provided evidence that boat noise can alter hearing threshold, affect physiological response, induce behavioral modifications, and mask communication in fishes (Hawkins and Popper, 2018). 
An increase in hearing thresholds (defined as the limit in decibels (dB) under which a sound is not perceived) has been observed in adults of brown meagre, damselfish and redmouthed goby, by using playbacks of boat noise. Such increases in hearing thresholds were associated with a decrease in hearing and communication range (Codarin et al., 2009). Celi et al. (2016) showed an increase in stress-related plasma variables (ACTH, cortisol, glucose, lactate, cholesterol, triglycerides, Hsp70, hematocrit and osmolarity) in adults of gilthead seabream after 10 days exposure in aquaria to a sound loop consisting of seven recreational vessels, a hydrofoil, a ferry and a fishing boat. Filiciotto et al. (2017) have reported changes in immune parameters, such as higher levels of lysozyme activity, antiprotease activity and white blood cells together with a lower albumin/globulin ratio in gilthead seabream after 40 days of exposure to a loop of recordings of different types of boats. Buscaino et al. (2010) found that the exposure of juvenile European seabass and gilthead seabream to linear sweeps in the frequency band in which most of the boat noises are produced induced an increase in lactate and hematocrit levels, as well as an increased mobility in both species, while a decrease in glucose was observed in gilthead seabream. Vazzana et al. (2017) exposed caged adult damselfishes during two minutes to an artificial noise consisting of pure tones aimed at reproducing the main acoustic energy produced by boat, ships and ferries. They found that this exposure induced an increase in stress biomarkers in blood, such as glucose, lactate, total proteins and Hsp70.

Resident adults of red-mouthed goby, a small-sized territorial benthic fish, were found to be more submissive and won less encounters while fighting against conspecific intruders in the presence of noise playbacks of a 5 m-fiberglass boat (Sebastianutto et al., 2011).

Alves et al. (2016) showed that masking induced by the presence of boat noise caused a reduction in the distance at which adult lusitanian toadfish were able to detect a conspecific from $6 \mathrm{~m}$ to 2.5-4 $\mathrm{m}$ and from $13 \mathrm{~m}$ to $7-8.5 \mathrm{~m}$, depending on the call and the type of boat noise.

The noise produced by boats at sea can affect individual and schooling behavior. Two field studies conducted on adult brown meagre showed that boat noise caused an increase both in the rate of vocalizations, probably to compensate communication masking (Picciulin et al., 2012), and in flight duration and frequency of hiding behaviors, followed by a rapid recovery after exposure (La Manna et al., 2016). Bracciali et al. (2012) reported an increased escape duration, the alterations of physiological conditions (Body Condition Index = Total weight / Standard length ${ }^{3}$ ) and a decrease in feeding frequency in adult damselfish exposed to boat noise in comparison to a navigation-restricted area. Palma et al. (2019) observed the 
displacement in $37.5 \%$ and an increased respiration rate in $87 \%$ of adult long-snouted seahorse during passages of motorboats over the specimens. A decrease in anti-predator response and an increase in startle latency has also been reported as a behavioral reaction to boat noise in adult European eel (Bruintjes et al., 2016a). Purser et al. (2016) also investigated the anti-predatory response and ventilation rate in juveniles of European eels. Their results were similar to those reported by Bruintjes et al. (2016a), but only when the fish were in bad body conditions. Blom et al. (2019) showed that continuous broadband noise, increased latency to female nest inspection and spawning, and decreased spawning probability in adult Common goby.

Sarà et al. (2007) observed that adults of Atlantic bluefin tuna caged in a tuna trap modified their schooling behavior during the passage of ferry boats next to the trap, suggesting that migration patterns to spawning and feeding grounds could be affected by boat noise. By using time-budget analyses during playbacks of a ferry boat and a fiberglass boat, Picciulin et al., (2010) reported a significant decrease in the time spent caring their nests in adults of damselfishes and an increase in the time spent sheltering in adults of red-mouthed goby. Similar behavioral changes have the potential to affect, besides the single individuals, whole populations, by decreasing offspring survival in damselfishes or decreasing the time dedicated to feeding and mating in red-mouthed goby. Finally, González Correa et al. (2019) found that fish call rates and complexity were higher in a location where mooring was not allowed compared to regulated mooring locations where motorboat noise was higher.

\section{Impact of MNP on invertebrates}

MNP has been found to induce multiple negative effects on invertebrates (Carroll et al., 2017). In the Mediterranean Sea, fifteen studies assessed potential effects of anthropogenic noise on marine invertebrates: six dealt with physiology, seven with behavior and two evaluated both; eight concerned crustacean species (the hermit crab Pagurus bernhardus, the spiny lobster Palinurus elephas, the common prawn Palaemon serratus), six cephalopods (the European squid Loligo vulgaris, the common cuttlefish Sepia officinalis, the common octopus Octopus vulgaris, the southern shortfin squid Illex coindetii) and one cnidarians (the Mediterranean jellyfish Cotylorhiza tuberculata, the barrel jellyfish Rhizostoma pulmo). See table 2 for a summary of the response variables tested for each species. 
In Table 1 of Supplementary Material more detail is provided about the studied species, the noise features (type, level, duration and frequency) and the location where the studies used in this review have been conducted.

\section{Acute MNP}

One study assessed the impact of acute MNP on crustaceans, and was conducted on adults of the hermit crab. Roberts et al. (2016) showed that an experimental apparatus generating noise types similar to anthropogenic activities, such as blasting and pile driving, may induce the retraction of antennas and reduce locomotion of the hermit crab in aquaria.

MNP studies on cephalopods in the Mediterranean Sea focused on four species: European squid, common cuttlefish, common octopus and southern shortfin squid. André et al. (2011) exposed adults of these four species to high-intensity low-frequency sounds, mimicking acute sounds produced by human activities like pile driving and air guns. These authors reported permanent and substantial alterations of the sensory hair cells of the statocysts, responsible for the animals' sense of balance and position in space, with damages increasing with time of exposure. These results were confirmed by Solé et al. (2013a, 2013b) who exposed adults of the same four species to the same sound sweeps, and observed typically noise-induced lesions in the statocysts, whose seriousness was correlated with time of exposure. Solé et al. (2017) observed the same damages on statocysts by exposing caged adults of common cuttlefish to different noises at different distances from the source in the field. Samson et al. (2014) assessed the response of juvenile and adult common cuttlefish exposed to pure-tone pips in aquaria and reported an escape response from sounds. The intensity of the response was related to the stimulus amplitude and sound frequency. After repeated exposure, some evidence of habituation was observed but a total response inhibition never occurred.

The only study focusing on cnidarians is the one of Solé et al. (2016), which reported injuries in the statocyst sensory epithelium in two medusajellyfish species (Mediterranean and barrel jellyfishes) after two hours of exposure to low frequency and high intensity sweeps.

\section{Chronic MNP}

Filiciotto et al. (2014) showed that adult spiny lobster exposed in controlled conditions to 30 min of boat noise playbacks recorded next to a harbor, display an increase in stressrelated haemolymphatic biomarkers (glucose, total proteins, Hsp70 and heamatocrit) and in 
locomotory activity reflecting a potential disturbance. Boat noise was also involved in the alteration of immune response (with a decrease in total haemocyte count and in phenoloxydase activity in cell-free haemolymph) and the increase in Hsp27 expression in haemocyte lysate of spiny lobsters (Celi et al., 2015). These results showed that boat noises may induce stressful conditions at both cellular and biochemical levels. The 30 mins exposure to boat noise on adult specimens of common prawn elicited an increase in protein concentration, Hsps 27 and 70 expressions, DNA fragmentation, and a decrease in locomotory activity as well as in the time spent for sheltering (Filiciotto et al., 2016). These impacts could decrease the probability of survival in the presence of a predator and lower the number of mate encounters, thus decreasing the reproductive success. Exposure to playbacks of boat noise, either produced by a large shipping vessel or a small outboard craft, can affect the behavior of the hermit crab inducing a greater response latency to a stimulus of looming predator, thus increasing predation risk and mortality by predation (Nousek-McGregor and Mei, 2016). Moreover, in two studies, Tidau and Briffa (2019a, 2019b) reported that the hermit crab displays clear grouping preferences with other individuals that is dependent on shell suitability (crabs with optimal shells prefer to stay in pairs, while crabs with suboptimal shells do not show any group preference). While exposed to boat noise, grouping preferences disappear or strongly change, and shell selection ability decreases (hermit crabs are less capable to select an optimal shell). Finally, Walsh et al. (2017) investigated the impact of white noise on the hermit crab in aquaria ; this type of noise is produced by combining different frequencies together, effectively simulating broadband noise like the noise produced by distant ships. In a noisy environment, shell selection was more rapid, with hermit crabs approaching faster the shells, decreasing the time spent for inspecting and entering the shells. This could induce a sub-optimal shell selection potentially decreasing individual survival probability.

For cephalopods, Kunc et al. (2014) reported that playbacks of ship noise can induce an increase in the frequency of livery (body coloration patterns) change in adult common cuttlefish.

\section{Conclusions, knowledge gaps and perspectives}

There is increasing evidence worldwide that MNP may represent a serious threat to marine life. Our review indicates that acute and chronic MNP can cause, in fact, a wide 
variety of effects on marine invertebrates (chiefly mollusks and crustaceans) and vertebrates (fishes and mammals) (Carroll et al., 2017; Rako-Gospić and Picciulin, 2019). Effects encompass behavioral alterations (e.g. swimming and gregarious patterns, anti-predator responses, mating and spawning patterns), auditory damage, communication masking (mostly intra-specific), stress-related non-auditory physiological responses, changes in habitat use (e.g. shelter frequentation), migration and displacement (e.g. towards less noisy places), or immediate death (e.g. as a consequence of severe internal organs' damages) (Aguilar de Soto et al., 2016; Cox et al., 2018; Hawkins and Popper, 2018).

The present review summarizes the available evidence about MNP effects specifically on Mediterranean fish and invertebrates. Fewer studies concerned marine invertebrates, while most of them dealt with fishes. Among the 30 reviewed studies assessing the effects of MNP on Mediterranean fish species, four did not detect any effect and 26 reported that MNP may have detectable negative repercussions. Negative effects ranged from mild modifications in physiological variables to extremely stressful conditions associated with decreased immune capacities and degraded body conditions. Behavior can also be impacted, with effects ranging from short displacements and slight changes in swimming behavior to compromising feeding and nest caring behaviors. These negative effects could impact both single individuals and entire populations. Such individual- to population-wide impacts have the potential to affect entire communities, especially when species playing key ecological roles are impacted (e.g. high-level predatory fishes; Guidetti, 2006). This review also showed that MNP can have impacts on physiology of many invertebrates (crustacean decapods, cephalopod mollusks and cnidarians), that can range from an increase in stress-related variables to permanent structural damages, possibly having fatal effects. Crustaceans and cephalopods, also, showed different degrees of potentially harmful behavioral responses, ranging from changes in movement patterns to increased latency in response against predators, possibly affecting individual reproductive success and survival. Most studies we have found are individual-based, but the effects of MNP could have population-wide repercussions, particularly when MNP is intense and/or chronic. Community- and ecosystem-wide effects may occur whenever MNP affects species that have crucial roles, such as habitat-former mollusks (e.g. oysters; Charifi et al., 2018) and high-level fish predators (Guidetti, 2006; Sarà et al., 2007).

MNP has the potential to affect a variety of species and among them some key species providing ecosystem goods and services, which justifies the increasing attention paid to marine noise pollution (MSFD; EU, 2008). This review showed that until now the available evidence for the Mediterranean was largely anecdotal, and limited to a few species (marine 
mammals excepted; see https://www.frontiersin.org/research-topics/8654/impacts-ofshipping-on-marine-fauna), a few variables (while marine noise may potentially impact from cells to ecosystems) and to snapshot or short-term studies carried out at a few locations. There is thus a clear need for more research and systematic monitoring to exhaustively assess the risks generated by MNP to marine life. Data gathering should be expanded in space and time, and should integrate multiple species and multiple variables, so to be capable of capturing information on both early symptoms and long-term permanent effects.

Also, MNP has generally been assessed without taking into account the variety of interactions it can have with other sources of environmental disturbance at sea, such as overfishing, climate change, acidification, chemical pollution and other forms of anthropogenic disturbance that can combine to ultimately influence the marine biodiversity in complex ways (Côté et al., 2016; Micheli et al., 2016). Purser et al. (2016), from this point of view, observed that only eels in bad health conditions were adversely affected by MNP, which suggests how important is to consider the potential synergistic effectsinteractions (synergies, antagonisms and additive effects, Côté et al., 2016) of different sources of disturbance at sea.

Environmental agencies, authorities, policy makers and legislators at all levels (e.g. at EU or at the Mediterranean scale) strongly need data to take proper management decisions, but presently there are still lots of unknown aspects about MNP (Erbe, 2013). More complete and integrated data would provide crucial information to set appropriate conservation and management/mitigation measures, which should be accompanied by effective educational campaigns and supporting legislations.

Based on our literature review we identified the following gaps in knowledge about the potential effects that MNP may have on Mediterranean fish and invertebrates:

1) some categories of marine organisms have been little investigated or totally ignored, such as i) invertebrates (especially groups like annelids and echinoderms), ii) elasmobranchs (in spite they are the most threatened fish group in the Mediterranean Sea and worldwide; see Ferretti et al. (2008, 2010) and Casper et al. (2012)), iii) early life stages (generally more sensitive to impacts than adults, see e.g. Simpson et al. (2016));

2) some biological variables/mechanisms have been little investigated or totally ignored as well, such as i) the hearing sensitivity of organisms (that has been investigated for a few species, so we do not actually know for how many species MNP can impair hearing and mask communications), ii) the bio-physiological mechanisms triggering the observed behavioral responses, iii) the ways MNP affects populations, communities and ecosystems, iv) the physiological variables potentially impacted by MNP stress (which is 
crucial, e.g., to properly evaluate energy metabolism changes, to characterize concentration variations for hormones potentially implied in stress responses), and v) omics (which could be useful to study long term adaptation of species subject to MNP stress);

3) a few studies assessed the potential of recovery, habituation and adaptation to MNP in relation e.g. to species' mobility, which is fundamental to understanding whether some responses are permanent or temporary;

4) most available studies focus on chronic MNP (almost all on boat noise), which is the most widespread type of MNP monitored by the MSFD, but not a priori the most impacting one;

5) methodologically speaking, many aspects would deserve to be investigated more in depth, such as i) the advantages of coupling field and laboratory approaches (whose lack often prevents the possibility to draw reliable and robust conclusions about the effects of the different types of MNP on the investigated species), ii) the limits to use organisms (especially fish) coming from aquaculture (which could be less sensitive or responsive than wild animals because of potential habituation or because they descend from cultured lineages exposed since birth to the noise of aquaculture facilities), iii) the effects of the acoustic configuration of the experimental units (e.g. aquaria) or the sea bottom (potentially hindering, modifying or stopping the noise stimulus produced, perceived or emitted by animals; see Rogers et al. (2016)), and iv) the spatial distribution of field studies (few field studies have been conducted in the Mediterranean Sea, and most of them are concentrated in the western sector or in the northern Adriatic Sea, while the rest of the basin and particularly some sectors that are likely to be "noise hotspots", like in the proximity of the Suez Canal, have not been investigated yet);

6) unusual sources of MNP and multi-stressors' interactions also would deserve more attention, such as i) the sources of noise generated by typically terrestrial human activities that are likely to propagate in the sea (e.g. by railway tracks or airports and heliport installations near the sea; see Urick (1972) and Erbe et al. (2018) for non-Mediterranean examples), and ii) the potential of climate change (which is going to modify the physical properties of marine waters) to increase the ambient noise levels in the future (Hester et al., 2008);

7) finally, more effort should be dedicated to improve regulations that, in the Mediterranean region, are limited to the obligation of Mediterranean EU countries to monitor the MNP 
in the framework of the MSFD and to swiftly enforce the limitations or use of silent engines in a few marine protected areas.

Even though gaps of information are still relevant, some measures aimed at mitigating if not locally eradicating MNP have already been proposed (Würsig et al., 2000; Dähne et al., 2013). As for other sources of pollution (e.g. plastic or chemical compounds), preventing the noise to be transmitted through the aquatic medium is a difficult task (conventional methods for physically reducing noise pollution on land, like noise barriers, can hardly work at sea). MNP can sometimes be mitigated, however, by reducing it at the source (see Merchant, 2019). Vessel circulation can be locally banned or re-routed away from sensitive sites and ecosystems, vessel numbers and/or speed can be reduced, e.g. within or in some parts of marine protected areas (Buscaino et al., 2016). Also, more silent motors, generators, hulls and propellers could be developed, combining such technical solutions with specific educational programs and laws implementing speed limits. Especially for acute MNP (e.g. construction works), bubble curtains have been used to effectively limit noise propagation (see e.g. Würsig et al., 2000). Even though evidence is limited and research is still in its infancy, recent studies report that some marine vegetation could contribute to reducing MNP (Wilson et al., 2013; Johnson et al., 2017). Finally, resource prospection methods could be switched to more silent ones (e.g. marine vibroseis to replace noisy air guns; Smith and Jenkerson, 1998).

In conclusion, taking into account i) that the interest in the economic potential of the oceans is escalating (Bennett et al., 2019; Jouffray et al., 2020), ii) that many human activities at sea causing significant MNP as a by-product (e.g. maritime traffic) keep increasing (Sardain et al., 2019) and iii) that the Mediterranean Sea is densely populated and is a crucial crossroad for many maritime routes, there is no reason to expect that MNP will decrease in the next future, unless innovative technical solutions, specific rules/laws and/or good practices are systematically adopted. It is, therefore, imperative that effective measures are fairly rapidly adopted, hopefully based on a clear internationally-based/shared legislation. This goes along with an enhancement of ecological awareness via education programs, in order to address the problem of MNP at the Mediterranean scale and mitigate its effects on marine life, from individual marine organisms to whole ecosystems. 


\section{References:}

Aguilar de Soto, N., Gkikopoulou, K., Hooker, S., Isojunno, S., Johnson, M., Miller, P., Tyack, P., Wensveen, P., Donovan, C., Harris, C.M., Harris, D., Marshall, L., Oedekoven, C., Prieto, R., Thomas, L., 2016. From physiology to policy: A review of physiological noise effects on marine fauna with implications for mitigation. Presented at the Fourth International Conference on the Effects of Noise on Aquatic Life, Dublin, Ireland, p. 040008. https://doi.org/10.1121/2.0000299

Akamatsu, T., Okumura, T., Novarini, N., Yan, H.Y., 2002. Empirical refinements applicable to the recording of fish sounds in small tanks. The Journal of the Acoustical Society of America 112, 3073-3082. https://doi.org/10.1121/1.1515799

Alves, D., Amorim, M.C.P., Fonseca, P.J., 2016. Boat noise reduces acoustic active space in the lusitanian toadfish Halobatrachus didactylus. Presented at the Fourth International Conference on the Effects of Noise on Aquatic Life, Dublin, Ireland, p. 010033. https://doi.org/10.1121/2.0000325

Amorim, M.C.P., 2006. Diversity of sound production in fish., in: Ladich, F., Collin, S.P., Moller, P., Kapoor, B.G. (Eds.), Communication in Fishes. pp. 71-104.

Anderson, P.A., Berzins, I.K., Fogarty, F., Hamlin, H.J., Guillette, L.J., 2011. Sound, stress, and seahorses: The consequences of a noisy environment to animal health. Aquaculture 311, 129-138. https://doi.org/10.1016/j.aquaculture.2010.11.013

André, M., Solé, M., Lenoir, M., Durfort, M., Quero, C., Mas, A., Lombarte, A., van der Schaar, M., López-Bejar, M., Morell, M., Zaugg, S., Houégnigan, L., 2011. Lowfrequency sounds induce acoustic trauma in cephalopods. Frontiers in Ecology and the Environment 9, 489-493. https://doi.org/10.1890/100124

Bennett, N.J., Cisneros-Montemayor, A.M., Blythe, J., Silver, J.J., Singh, G., Andrews, N., Calò, A., Christie, P., Di Franco, A., Finkbeiner, E.M., Gelcich, S., Guidetti, P., Harper, S., Hotte, N., Kittinger, J.N., Le Billon, P., Lister, J., López de la Lama, R., McKinley, E., Scholtens, J., Solås, A.-M., Sowman, M., Talloni-Álvarez, N., Teh, L.C.L., Voyer, M., Sumaila, U.R., 2019. Towards a sustainable and equitable blue economy. Nat Sustain 2, 991-993. https://doi.org/10.1038/s41893-019-0404-1

Blom, E.-L., Kvarnemo, C., Dekhla, I., Schöld, S., Andersson, M.H., Svensson, O., Amorim, M.Clara.P., 2019. Continuous but not intermittent noise has a negative impact on mating success in a marine fish with paternal care. Scientific Reports 9, 5494. https://doi.org/10.1038/s41598-019-41786-X

Bolle, L.J., de Jong, C.A.F., Bierman, S.M., van Beek, P.J.G., van Keeken, O.A., Wessels, P.W., van Damme, C.J.G., Winter, H.V., de Haan, D., Dekeling, R.P.A., 2012. Common Sole Larvae Survive High Levels of Pile-Driving Sound in Controlled Exposure Experiments. PLoS ONE 7, e33052. https://doi.org/10.1371/journal.pone.0033052

Bracciali, C., Campobello, D., Giacoma, C., Sarà, G., 2012. Effects of Nautical Traffic and Noise on Foraging Patterns of Mediterranean Damselfish (Chromis chromis). PLoS ONE 7, e40582. https://doi.org/10.1371/journal.pone.0040582

Bruintjes, R., Purser, J., Everley, K.A., Mangan, S., Simpson, S.D., Radford, A.N., 2016a. Rapid recovery following short-term acoustic disturbance in two fish species. Royal Society Open Science 3, 150686. https://doi.org/10.1098/rsos.150686

Bruintjes, R., Simpson, S.D., Harding, H., Bunce, T., Benson, T., Rossington, K., Jones, D., 2016b. The impact of experimental impact pile driving on oxygen uptake in black seabream and plaice. Presented at the Fourth International Conference on the Effects of Noise on Aquatic Life, Dublin, Ireland, p. 010042.

https://doi.org/10.1121/2.0000422 
Buscaino, G., Ceraulo, M., Pieretti, N., Corrias, V., Farina, A., Filiciotto, F., Maccarrone, V., Grammauta, R., Caruso, F., Giuseppe, A., Mazzola, S., 2016. Temporal patterns in the soundscape of the shallow waters of a Mediterranean marine protected area. Scientific Reports 6. https://doi.org/10.1038/srep34230

Buscaino, G., Filiciotto, F., Buffa, G., Bellante, A., Stefano, V.D., Assenza, A., Fazio, F., Caola, G., Mazzola, S., 2010. Impact of an acoustic stimulus on the motility and blood parameters of European sea bass (Dicentrarchus labrax L.) and gilthead sea bream (Sparus aurata L.). Marine Environmental Research 69, 136-142. https://doi.org/10.1016/j.marenvres.2009.09.004

Carroll, A.G., Przeslawski, R., Duncan, A., Gunning, M., Bruce, B., 2017. A critical review of the potential impacts of marine seismic surveys on fish \& invertebrates. Marine Pollution Bulletin 114, 9-24. https://doi.org/10.1016/j.marpolbul.2016.11.038

Casper, B.M., Halvorsen, M.B., Popper, A.N., 2012. Are Sharks Even Bothered by a Noisy Environment?, in: Popper, A.N., Hawkins, A. (Eds.), The Effects of Noise on Aquatic Life. Springer New York, New York, NY, pp. 93-97. https://doi.org/10.1007/978-14419-7311-5_20

Celi, M., Filiciotto, F., Maricchiolo, G., Genovese, L., Quinci, E.M., Maccarrone, V., Mazzola, S., Vazzana, M., Buscaino, G., 2016. Vessel noise pollution as a human threat to fish: assessment of the stress response in gilthead sea bream (Sparus aurata, Linnaeus 1758). Fish Physiology and Biochemistry 42, 631-641. https://doi.org/10.1007/s10695-015-0165-3

Celi, M., Filiciotto, F., Vazzana, M., Arizza, V., Maccarrone, V., Ceraulo, M., Mazzola, S., Buscaino, G., 2015. Shipping noise affecting immune responses of European spiny lobster (Palinurus elephas). Canadian Journal of Zoology 93, 113-121. https://doi.org/10.1139/cjz-2014-0219

Charifi, M., Miserazzi, A., Sow, M., Perrigault, M., Gonzalez, P., Ciret, P., Benomar, S., Massabuau, J.-C., 2018. Noise pollution limits metal bioaccumulation and growth rate in a filter feeder, the Pacific oyster Magallana gigas. PLOS ONE 13, e0194174. https://doi.org/10.1371/journal.pone.0194174

Codarin, A., Wysocki, L.E., Ladich, F., Picciulin, M., 2009. Effects of ambient and boat noise on hearing and communication in three fish species living in a marine protected area (Miramare, Italy). Marine Pollution Bulletin 58, 1880-1887. https://doi.org/10.1016/j.marpolbul.2009.07.011

Côté, I.M., Darling, E.S., Brown, C.J., 2016. Interactions among ecosystem stressors and their importance in conservation. Proc. R. Soc. B 283, 20152592. https://doi.org/10.1098/rspb.2015.2592

Cox, K., Brennan, L.P., Gerwing, T.G., Dudas, S.E., Juanes, F., 2018. Sound the alarm: A meta-analysis on the effect of aquatic noise on fish behavior and physiology. Global Change Biology 24, 3105-3116. https://doi.org/10.1111/gcb.14106

Dähne, M., Gilles, A., Lucke, K., Peschko, V., Adler, S., Krügel, K., Sundermeyer, J., Siebert, U., 2013. Effects of pile-driving on harbour porpoises ( Phocoena phocoena ) at the first offshore wind farm in Germany. Environmental Research Letters 8, 025002. https://doi.org/10.1088/1748-9326/8/2/025002

Debusschere, E., De Coensel, B., Bajek, A., Botteldooren, D., Hostens, K., Vanaverbeke, J., Vandendriessche, S., Van Ginderdeuren, K., Vincx, M., Degraer, S., 2014. In Situ Mortality Experiments with Juvenile Sea Bass (Dicentrarchus labrax) in Relation to Impulsive Sound Levels Caused by Pile Driving of Windmill Foundations. PLoS ONE 9, e109280. https://doi.org/10.1371/journal.pone.0109280

Debusschere, E., Hostens, K., Adriaens, D., Ampe, B., Botteldooren, D., De Boeck, G., De Muynck, A., Sinha, A.K., Vandendriessche, S., Van Hoorebeke, L., Vincx, M., 
Degraer, S., 2016. Acoustic stress responses in juvenile sea bass Dicentrarchus labrax induced by offshore pile driving. Environmental Pollution 208, 747-757.

https://doi.org/10.1016/j.envpol.2015.10.055

Duncan, A.J., Lucke, K., Erbe, C., McCauley, R.D., 2016. Issues associated with sound exposure experiments in tanks. Presented at the Fourth International Conference on the Effects of Noise on Aquatic Life, Dublin, Ireland, p. 070008.

https://doi.org/10.1121/2.0000280

Eddy, T.D., Lotze, H.K., Fulton, E.A., Coll, M., Ainsworth, C.H., de Araújo, J.N., Bulman, C.M., Bundy, A., Christensen, V., Field, J.C., Gribble, N.A., Hasan, M., Mackinson, S., Townsend, H., 2017. Ecosystem effects of invertebrate fisheries. Fish Fish 18, 4053. https://doi.org/10.1111/faf.12165

Erbe, C., 2013. International regulation of underwater noise, in: Acoustics Australia. pp. 1219.

Erbe, C., 2002. Underwater noise of whale-watching boats and potential effects on killer whales (Orcinus orca), base on an acoustic impact model. Marine Mammal Science 18, 394-418. https://doi.org/10.1111/j.1748-7692.2002.tb01045.x

Erbe, C., Reichmuth, C., Cunningham, K., Lucke, K., Dooling, R., 2016. Communication masking in marine mammals: A review and research strategy. Marine Pollution Bulletin 103, 15-38. https://doi.org/10.1016/j.marpolbul.2015.12.007

Erbe, C., Williams, R., Parsons, M., Parsons, S.K., Hendrawan, I.G., Dewantama, I.M.I., 2018. Underwater noise from airplanes: An overlooked source of ocean noise. Marine Pollution Bulletin 137, 656-661. https://doi.org/10.1016/j.marpolbul.2018.10.064

Fernández, A., Edwards, J.F., Rodríguez, F., de los Monteros, A.E., Herráez, P., Castro, P., Jaber, J.R., Martín, V., Arbelo, M., 2005. “Gas and Fat Embolic Syndrome” Involving a Mass Stranding of Beaked Whales (Family Ziphiidae) Exposed to Anthropogenic Sonar Signals. Veterinary Pathology 42, 446-457. https://doi.org/10.1354/vp.42-4-446

Ferretti, F., Myers, R.A., Serena, F., Lotze, H.K., 2008. Loss of Large Predatory Sharks from the Mediterranean Sea: Large Sharks in the Mediterranean. Conservation Biology 22, 952-964. https://doi.org/10.1111/j.1523-1739.2008.00938.x

Ferretti, F., Worm, B., Britten, G.L., Heithaus, M.R., Lotze, H.K., 2010. Patterns and ecosystem consequences of shark declines in the ocean: Ecosystem consequences of shark declines. Ecology Letters no-no. https://doi.org/10.1111/j.14610248.2010.01489.x

Filiciotto, F., Cecchini, S., Buscaino, G., Maccarrone, V., Piccione, G., Fazio, F., 2017. Impact of aquatic acoustic noise on oxidative status and some immune parameters in gilthead sea bream Sparus aurata (Linnaeus, 1758) juveniles. Aquaculture Research 48, 18951903. https://doi.org/10.1111/are.13027

Filiciotto, F., Vazzana, M., Celi, M., Maccarrone, V., Ceraulo, M., Buffa, G., Arizza, V., de Vincenzi, G., Grammauta, R., Mazzola, S., Buscaino, G., 2016. Underwater noise from boats: Measurement of its influence on the behaviour and biochemistry of the common prawn ( Palaemon serratus, Pennant 1777). Journal of Experimental Marine Biology and Ecology 478, 24-33. https://doi.org/10.1016/j.jembe.2016.01.014

Filiciotto, F., Vazzana, M., Celi, M., Maccarrone, V., Ceraulo, M., Buffa, G., Stefano, V.D., Mazzola, S., Buscaino, G., 2014. Behavioural and biochemical stress responses of Palinurus elephas after exposure to boat noise pollution in tank. Marine Pollution Bulletin 84, 104-114. https://doi.org/10.1016/j.marpolbul.2014.05.029

Frisk, G.V., 2012. Noiseonomics: The relationship between ambient noise levels in the sea and global economic trends. Scientific Reports 2, 437. https://doi.org/10.1038/srep00437 
González Correa, J.M., Bayle Sempere, J.-T., Juanes, F., Rountree, R., Ruíz, J.F., Ramis, J., 2019. Recreational boat traffic effects on fish assemblages: First evidence of detrimental consequences at regulated mooring zones in sensitive marine areas detected by passive acoustics. Ocean \& Coastal Management 168, 22-34. https://doi.org/10.1016/j.ocecoaman.2018.10.027

Götz, T., Janik, V., 2013. Acoustic deterrent devices to prevent pinniped depredation: efficiency, conservation concerns and possible solutions. Marine Ecology Progress Series 492, 285-302. https://doi.org/10.3354/meps10482

Guidetti, P., 2006. Marine Reserves Reestablish Lost Predatory Interactions And Cause Community Changes In Rocky Reefs. Ecological Applications 16, 963-976. https://doi.org/10.1890/1051-0761(2006)016[0963:MRRLPI]2.0.CO;2

Halvorsen, M.B., Casper, B.M., Matthews, F., Carlson, T.J., Popper, A.N., 2012. Effects of exposure to pile-driving sounds on the lake sturgeon, Nile tilapia and hogchoker. Proceedings of the Royal Society B: Biological Sciences 279, 4705-4714. https://doi.org/10.1098/rspb.2012.1544

Hammerschlag, N., Schmitz, O.J., Flecker, A.S., Lafferty, K.D., Sih, A., Atwood, T.B., Gallagher, A.J., Irschick, D.J., Skubel, R., Cooke, S.J., 2019. Ecosystem Function and Services of Aquatic Predators in the Anthropocene. Trends in Ecology \& Evolution 34, 369-383. https://doi.org/10.1016/j.tree.2019.01.005

Hatch, L.T., Clark, C.W., Van Parijs, S.M., Frankel, A.S., Ponirakis, D.W., 2012. Quantifying Loss of Acoustic Communication Space for Right Whales in and around a U.S. National Marine Sanctuary: Hatch et al . Conservation Biology 26, 983-994. https://doi.org/10.1111/j.1523-1739.2012.01908.x

Hawkins, A.D., Popper, A.N., 2018. Effects of Man-Made Sound on Fishes, in: Slabbekoorn, H., Dooling, R.J., Popper, A.N., Fay, R.R. (Eds.), Effects of Anthropogenic Noise on Animals. Springer New York, New York, NY, pp. 145-177. https://doi.org/10.1007/978-1-4939-8574-6_6

Hawkins, A.D., Roberts, L., Cheesman, S., 2014. Responses of free-living coastal pelagic fish to impulsive sounds. The Journal of the Acoustical Society of America 135, 31013116. https://doi.org/10.1121/1.4870697

Herbert-Read, J.E., Kremer, L., Bruintjes, R., Radford, A.N., Ioannou, C.C., 2017. Anthropogenic noise pollution from pile-driving disrupts the structure and dynamics of fish shoals. Proceedings of the Royal Society B: Biological Sciences 284, 20171627. https://doi.org/10.1098/rspb.2017.1627

Hester, K.C., Peltzer, E.T., Kirkwood, W.J., Brewer, P.G., 2008. Unanticipated consequences of ocean acidification: A noisier ocean at lower pH. Geophysical Research Letters 35. https://doi.org/10.1029/2008GL034913

Hildebrand, J., 2009. Anthropogenic and natural sources of ambient noise in the ocean. Marine Ecology Progress Series 395, 5-20. https://doi.org/10.3354/meps08353

Holmlund, C.M., Hammer, M., 1999. Ecosystem services generated by fish populations. Ecological Economics 29, 253-268. https://doi.org/10.1016/S0921-8009(99)00015-4

Holt, D.E., Johnston, C.E., 2011. Can you hear the dinner bell? Response of cyprinid fishes to environmental acoustic cues. Animal Behaviour 82, 529-534. https://doi.org/10.1016/j.anbehav.2011.06.004

Hu, M.Y., Yan, H.Y., Chung, W.-S., Shiao, J.-C., Hwang, P.-P., 2009. Acoustically evoked potentials in two cephalopods inferred using the auditory brainstem response (ABR) approach. Comparative Biochemistry and Physiology Part A: Molecular \& Integrative Physiology 153, 278-283. https://doi.org/10.1016/j.cbpa.2009.02.040 
Johnson, J.R., Venegas, G.R., Wilson, P.S., Hermand, J.-P., 2017. Low frequency acoustic properties of Posidonia oceanica seagrass leaf blades. The Journal of the Acoustical Society of America 141, EL555-EL560. https://doi.org/10.1121/1.4984045

Jouffray, J.-B., Blasiak, R., Norström, A.V., Österblom, H., Nyström, M., 2020. The Blue Acceleration: The Trajectory of Human Expansion into the Ocean. One Earth 2, 4354. https://doi.org/10.1016/j.oneear.2019.12.016

Kastelein, R.A., van der Heul, S., van der Veen, J., Verboom, W.C., Jennings, N., de Haan, D., Reijnders, P.J.H., 2007. Effects of acoustic alarms, designed to reduce small cetacean bycatch in gillnet fisheries, on the behaviour of North Sea fish species in a large tank. Marine Environmental Research 64, 160-180. https://doi.org/10.1016/j.marenvres.2006.12.012

Kunc, H.P., Lyons, G.N., Sigwart, J.D., McLaughlin, K.E., Houghton, J.D.R., 2014. Anthropogenic Noise Affects Behavior across Sensory Modalities. The American Naturalist 184, E93-E100. https://doi.org/10.1086/677545

La Manna, G., Manghi, M., Perretti, F., Sarà, G., 2016. Behavioral response of brown meagre ( Sciaena umbra ) to boat noise. Marine Pollution Bulletin 110, 324-334. https://doi.org/10.1016/j.marpolbul.2016.06.045

Ladich, F., 2019. Ecology of sound communication in fishes. Fish and Fisheries faf.12368. https://doi.org/10.1111/faf.12368

Merchant, N.D., 2019. Underwater noise abatement: Economic factors and policy options. Environmental Science \& Policy 92, 116-123. https://doi.org/10.1016/j.envsci.2018.11.014

Micheli, F., Halpern, B.S., Walbridge, S., Ciriaco, S., Ferretti, F., Fraschetti, S., Lewison, R., Nykjaer, L., Rosenberg, A.A., 2013. Cumulative Human Impacts on Mediterranean and Black Sea Marine Ecosystems: Assessing Current Pressures and Opportunities. PLoS ONE 8, e79889. https://doi.org/10.1371/journal.pone.0079889

Micheli, F., Heiman, K.W., Kappel, C.V., Martone, R.G., Sethi, S.A., Osio, G.C., Fraschetti, S., Shelton, A.O., Tanner, J.M., 2016. Combined impacts of natural and human disturbances on rocky shore communities. Ocean \& Coastal Management 126, 42-50. https://doi.org/10.1016/j.ocecoaman.2016.03.014

Montgomery, J., Tolimieri, N., Jeffs, A., 2002. Larval orientation to reefs and reef sound. The Journal of the Acoustical Society of America 112, 2203-2203. https://doi.org/10.1121/1.4778668

Neo, Y.Y., Hubert, J., Bolle, L., Winter, H.V., ten Cate, C., Slabbekoorn, H., 2016. Sound exposure changes European seabass behaviour in a large outdoor floating pen: Effects of temporal structure and a ramp-up procedure. Environmental Pollution 214, 26-34. https://doi.org/10.1016/j.envpol.2016.03.075

Neo, Y.Y., Seitz, J., Kastelein, R.A., Winter, H.V., ten Cate, C., Slabbekoorn, H., 2014. Temporal structure of sound affects behavioural recovery from noise impact in European seabass. Biological Conservation 178, 65-73. https://doi.org/10.1016/j.biocon.2014.07.012

Neo, Y.Y., Ufkes, E., Kastelein, R.A., Winter, H.V., ten Cate, C., Slabbekoorn, H., 2015. Impulsive sounds change European seabass swimming patterns: Influence of pulse repetition interval. Marine Pollution Bulletin 97, 111-117. https://doi.org/10.1016/j.marpolbul.2015.06.027

Nousek-McGregor, A.E., Mei, F.T.L., 2016. Does Noise From Shipping and Boat Traffic Affect Predator Vigilance in the European Common Hermit Crab?, in: Popper, A.N., Hawkins, A. (Eds.), The Effects of Noise on Aquatic Life II. Springer New York, New York, NY, pp. 767-774. https://doi.org/10.1007/978-1-4939-2981-8_94 
Nowacek, D.P., Thorne, L.H., Johnston, D.W., Tyack, P.L., 2007. Responses of cetaceans to anthropogenic noise. Mammal Review 37, 81-115. https://doi.org/10.1111/j.13652907.2007.00104.x

Palma, J., Magalhães, M., Correia, M., Andrade, J.P., 2019. Effects of anthropogenic noise as a source of acoustic stress in wild populations of Hippocampus guttulatus in the Ria Formosa, south Portugal. Aquatic Conservation: Marine and Freshwater Ecosystems aqc.3056. https://doi.org/10.1002/aqc.3056

Parvulescu, A., 1967. The acoustics of small tanks, in: Tavolga, W. (Ed.), Marine Bioacoustics. Pergamon Press, Oxford, pp. 7-13.

Patek, S.N., Shipp, L.E., Staaterman, E.R., 2009. The acoustics and acoustic behavior of the California spiny lobster (Panulirus interruptus). The Journal of the Acoustical Society of America 125, 3434. https://doi.org/10.1121/1.3097760

Peirano, A., Morri, C., Mastronuzzi, G., Bianchi, C.N., 1998. The coral Cladocora caespitosa (Anthozoa, Scleractinia) as a bioherm builder in the Mediterranean Sea. Memorie descrittive della Carta geologica d'Italia 52, 59-74.

Picciulin, M., Sebastianutto, L., Codarin, A., Calcagno, G., Ferrero, E.A., 2012. Brown meagre vocalization rate increases during repetitive boat noise exposures: A possible case of vocal compensation. The Journal of the Acoustical Society of America 132, 3118-3124. https://doi.org/10.1121/1.4756928

Picciulin, M., Sebastianutto, L., Codarin, A., Farina, A., Ferrero, E.A., 2010. In situ behavioural responses to boat noise exposure of Gobius cruentatus (Gmelin, 1789; fam. Gobiidae) and Chromis chromis (Linnaeus, 1758; fam. Pomacentridae) living in a Marine Protected Area. Journal of Experimental Marine Biology and Ecology 386, 125-132. https://doi.org/10.1016/j.jembe.2010.02.012

Pinnegar, J.K., 2018. Why the damselfish Chromis chromis is a key species in the Mediterranean rocky littoral - a quantitative perspective: CHROMIS CHROMIS IN THE MEDITERRANEAN SEA. J Fish Biol 92, 851-872. https://doi.org/10.1111/jfb.13551

Pitacco, V., Crocetta, F., Orlando-Bonaca, M., Mavrič, B., Lipej, L., 2017. The Mediterranean stony coral Cladocora caespitosa (Linnaeus, 1767) as habitat provider for molluscs: colony size effect. Journal of Sea Research 129, 1-11. https://doi.org/10.1016/j.seares.2017.08.001

Popper, A.N., Salmon, M., Horch, K.W., 2001. Acoustic detection and communication by decapod crustaceans. J. Comp. Physiol. A 187, 83-89.

Purser, J., Bruintjes, R., Simpson, S.D., Radford, A.N., 2016. Condition-dependent physiological and behavioural responses to anthropogenic noise. Physiology \& Behavior 155, 157-161. https://doi.org/10.1016/j.physbeh.2015.12.010

Radford, A.N., Lèbre, L., Lecaillon, G., Nedelec, S.L., Simpson, S.D., 2016. Repeated exposure reduces the response to impulsive noise in European seabass. Global Change Biology 22, 3349-3360. https://doi.org/10.1111/gcb.13352

Rako-Gospić, N., Picciulin, M., 2019. Underwater Noise: Sources and Effects on Marine Life, in: World Seas: An Environmental Evaluation. Elsevier, pp. 367-389. https://doi.org/10.1016/B978-0-12-805052-1.00023-1

Roberts, L., Cheesman, S., Elliott, M., Breithaupt, T., 2016. Sensitivity of Pagurus bernhardus (L.) to substrate-borne vibration and anthropogenic noise. Journal of Experimental Marine Biology and Ecology 474, 185-194. https://doi.org/10.1016/j.jembe.2015.09.014

Rogers, P.H., Hawkins, A.D., Popper, A.N., Fay, R.R., Gray, M.D., 2016. Parvulescu Revisited: Small Tank Acoustics for Bioacousticians, in: Popper, A.N., Hawkins, A. 
(Eds.), The Effects of Noise on Aquatic Life II. Springer New York, New York, NY, pp. 933-941. https://doi.org/10.1007/978-1-4939-2981-8_115

Samson, J.E., Mooney, T.A., Gussekloo, S.W.S., Hanlon, R.T., 2014. Graded behavioral responses and habituation to sound in the common cuttlefish Sepia officinalis. Journal of Experimental Biology 217, 4347-4355. https://doi.org/10.1242/jeb.113365

Santulli, A., Modica, A., Messina, C., Ceffa, L., Curatolo, A., Rivas, G., Fabi, G., D’Amelio, V., 1999. Biochemical Responses of European Sea Bass (Dicentrarchus labrax L.) to the Stress Induced by Off Shore Experimental Seismic Prospecting. Marine Pollution Bulletin 38, 1105-1114. https://doi.org/10.1016/S0025-326X(99)00136-8

Sarà, G., Dean, J., D’Amato, D., Buscaino, G., Oliveri, A., Genovese, S., Ferro, S., Buffa, G., Martire, M., Mazzola, S., 2007. Effect of boat noise on the behaviour of bluefin tuna Thunnus thynnus in the Mediterranean Sea. Marine Ecology Progress Series 331, 243253. https://doi.org/10.3354/meps331243

Sardain, A., Sardain, E., Leung, B., 2019. Global forecasts of shipping traffic and biological invasions to 2050. Nat Sustain 2, 274-282. https://doi.org/10.1038/s41893-019-0245-y

Sebastianutto, L., Picciulin, M., Costantini, M., Ferrero, E.A., 2011. How boat noise affects an ecologically crucial behaviour: the case of territoriality in Gobius cruentatus (Gobiidae). Environmental Biology of Fishes 92, 207-215. https://doi.org/10.1007/s10641-011-9834-y

Simpson, S.D., Radford, A.N., Holles, S., Ferarri, M.C.O., Chivers, D.P., McCormick, M.I., Meekan, M.G., 2016. Small-Boat Noise Impacts Natural Settlement Behavior of Coral Reef Fish Larvae, in: Popper, A.N., Hawkins, A. (Eds.), The Effects of Noise on Aquatic Life II. Springer New York, New York, NY, pp. 1041-1048. https://doi.org/10.1007/978-1-4939-2981-8_129

Slabbekoorn, H., Bouton, N., van Opzeeland, I., Coers, A., ten Cate, C., Popper, A.N., 2010. A noisy spring: the impact of globally rising underwater sound levels on fish. Trends in Ecology \& Evolution 25, 419-427. https://doi.org/10.1016/j.tree.2010.04.005

Smith, J.G., Jenkerson, M.R., 1998. Acquiring and processing marine vibrator data in the transition zone, in: SEG Technical Program Expanded Abstracts 1998. Presented at the SEG Technical Program Expanded Abstracts 1998, Society of Exploration Geophysicists, pp. 136-139. https://doi.org/10.1190/1.1820159

Solé, M., Lenoir, M., Durfort, M., López-Bejar, M., Lombarte, A., André, M., 2013a. Ultrastructural Damage of Loligo vulgaris and Illex coindetii statocysts after Low Frequency Sound Exposure. PLoS ONE 8, e78825. https://doi.org/10.1371/journal.pone.0078825

Solé, M., Lenoir, M., Durfort, M., López-Bejar, M., Lombarte, A., van der Schaar, M., André, M., 2013b. Does exposure to noise from human activities compromise sensory information from cephalopod statocysts? Deep Sea Research Part II: Topical Studies in Oceanography 95, 160-181. https://doi.org/10.1016/j.dsr2.2012.10.006

Solé, M., Lenoir, M., Fontuño, J.M., Durfort, M., van der Schaar, M., André, M., 2016. Evidence of Cnidarians sensitivity to sound after exposure to low frequency noise underwater sources. Sci Rep 6, 37979. https://doi.org/10.1038/srep37979

Solé, M., Sigray, P., Lenoir, M., van der Schaar, M., Lalander, E., André, M., 2017. Offshore exposure experiments on cuttlefish indicate received sound pressure and particle motion levels associated with acoustic trauma. Scientific Reports 7. https://doi.org/10.1038/srep45899

Tidau, S., Briffa, M., 2019a. Anthropogenic noise pollution reverses grouping behaviour in hermit crabs. Animal Behaviour 151, 113-120. https://doi.org/10.1016/j.anbehav.2019.03.010 
Tidau, S., Briffa, M., 2019b. Distracted decision makers: ship noise and predation risk change shell choice in hermit crabs. Behavioral Ecology arz064. https://doi.org/10.1093/beheco/arz064

Tidau, S., Briffa, M., 2016. Review on behavioral impacts of aquatic noise on crustaceans. Presented at the Fourth International Conference on the Effects of Noise on Aquatic Life, Dublin, Ireland, p. 010028. https://doi.org/10.1121/2.0000302

Tolimieri, N., Jeffs, A., Montgomery, J., 2000. Ambient sound as a cue for navigation by the pelagic larvae of reef fishes. Marine Ecology Progress Series 207, 219-224. https://doi.org/10.3354/meps207219

Tolley, S. gregory, Volety, A.K., 2005. THE ROLE OF OYSTERS IN HABITAT USE OF OYSTER REEFS BY RESIDENT FISHES AND DECAPOD CRUSTACEANS. Journal of Shellfish Research 24, 1007-1012. https://doi.org/10.2983/07308000(2005)24[1007:TROOIH]2.0.CO;2

Underwood, A.J., 1997. Experiments in ecology: their logical design and interpretation using analysis of variance. J. Mar. Biol. Ass. 77, 572. https://doi.org/10.1017/S0025315400072064

Urick, R.J., 1972. Noise Signature of an Aircraft in Level Flight over a Hydrophone in the Sea. The Journal of the Acoustical Society of America 52, 993-999. https://doi.org/10.1121/1.1913206

Vazzana, M., Celi, M., Arizza, V., Calandra, G., Buscaino, G., Ferrantelli, V., Bracciali, C., Sarà, G., 2017. Noise elicits hematological stress parameters in Mediterranean damselfish ( Chromis chromis , perciformes): A mesocosm study. Fish \& Shellfish Immunology 62, 147-152. https://doi.org/10.1016/j.fsi.2017.01.022

Walsh, E.P., Arnott, G., Kunc, H.P., 2017. Noise affects resource assessment in an invertebrate. Biology Letters 13, 20170098. https://doi.org/10.1098/rsbl.2017.0098

Weilgart, L., 2018. THE IMPACT OF OCEAN NOISE POLLUTION ON FISH AND INVERTEBRATES. Report for OceanCare 34.

Weilgart, L., 2017. Din of the Deep: Noise in the Ocean and Its Impacts on Cetaceans, in: Butterworth, A. (Ed.), Marine Mammal Welfare. Springer International Publishing, Cham, pp. 111-124. https://doi.org/10.1007/978-3-319-46994-2_7

Wilson, C., Wilson, P., Greene, C., Dunton, K., 2013. Seagrass meadows provide an acoustic refuge for estuarine fish. Mar. Ecol. Prog. Ser. 472, 117-127. https://doi.org/10.3354/meps10045

Wilson, M., Acolas, M.-L., Bégout, M.-L., Madsen, P.T., Wahlberg, M., 2008. Allis shad ( Alosa alosa) exhibit an intensity-graded behavioral response when exposed to ultrasound. The Journal of the Acoustical Society of America 124, EL243-EL247. https://doi.org/10.1121/1.2960899

Wright, A.J., Soto, N.A., Baldwin, A.L., Bateson, M., Beale, C.M., Clark, C., Deak, T., Edwards, E.F., FernÃ, A., 2007. Do Marine Mammals Experience Stress Related to Anthropogenic Noise? UCLA 20, 274-316.

Würsig, B., Greene, C.R., Jefferson, T.A., 2000. Development of an air bubble curtain to reduce underwater noise of percussive piling. Marine Environmental Research 49, 7993. https://doi.org/10.1016/S0141-1136(99)00050-1

\section{Acknowledgements:}

This work has been partially supported by MarineTraffic (MarineTraffic - Global Ship Tracking Intelligence www.marinetraffic.com) 



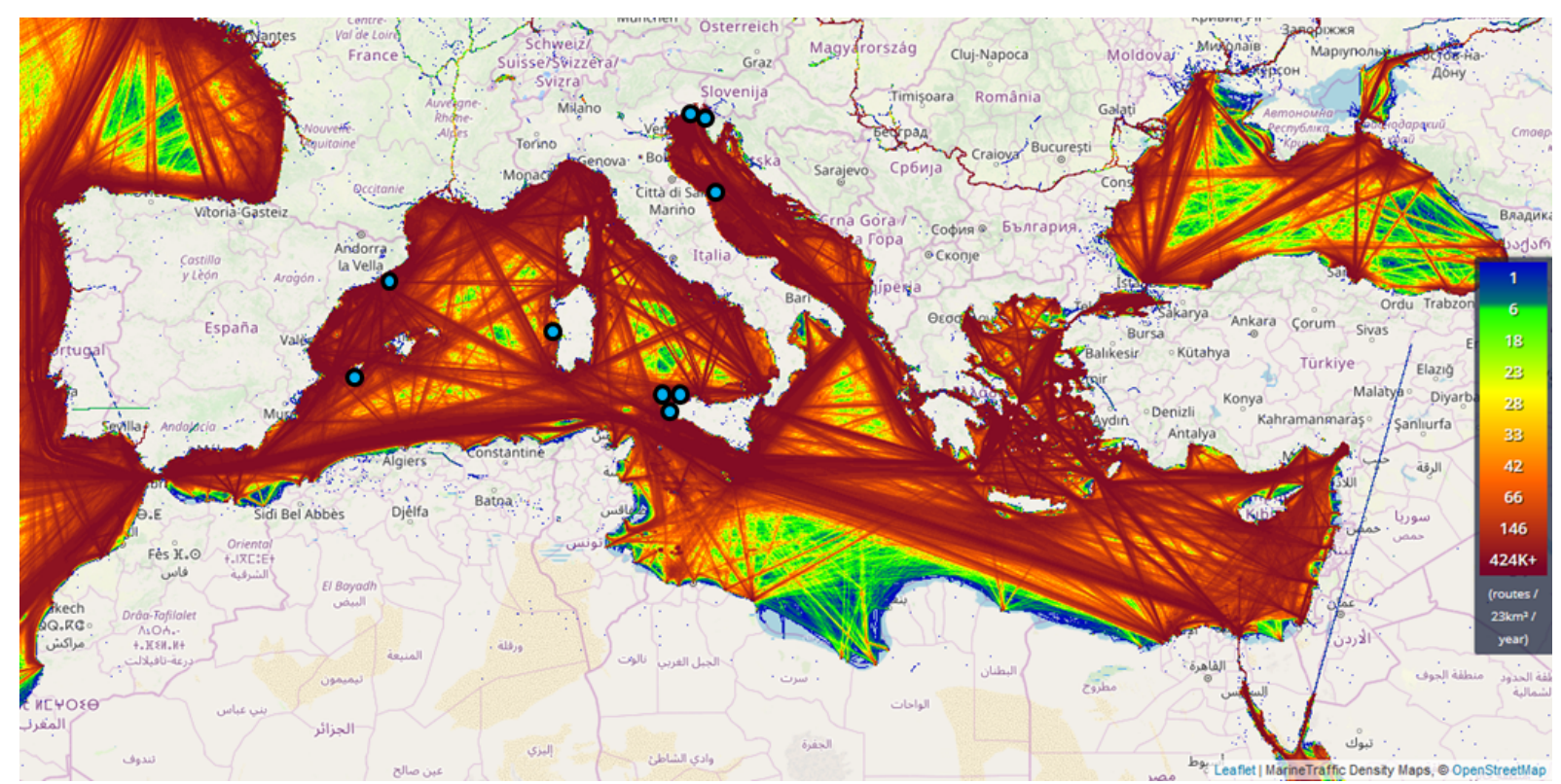

Figure 1: Map representing the main routes of maritime traffic in the Mediterranean Sea and the distribution of field studies (blue dots) (data from MarineTraffic - Global Ship Tracking Intelligence; www.marinetraffic.com). 


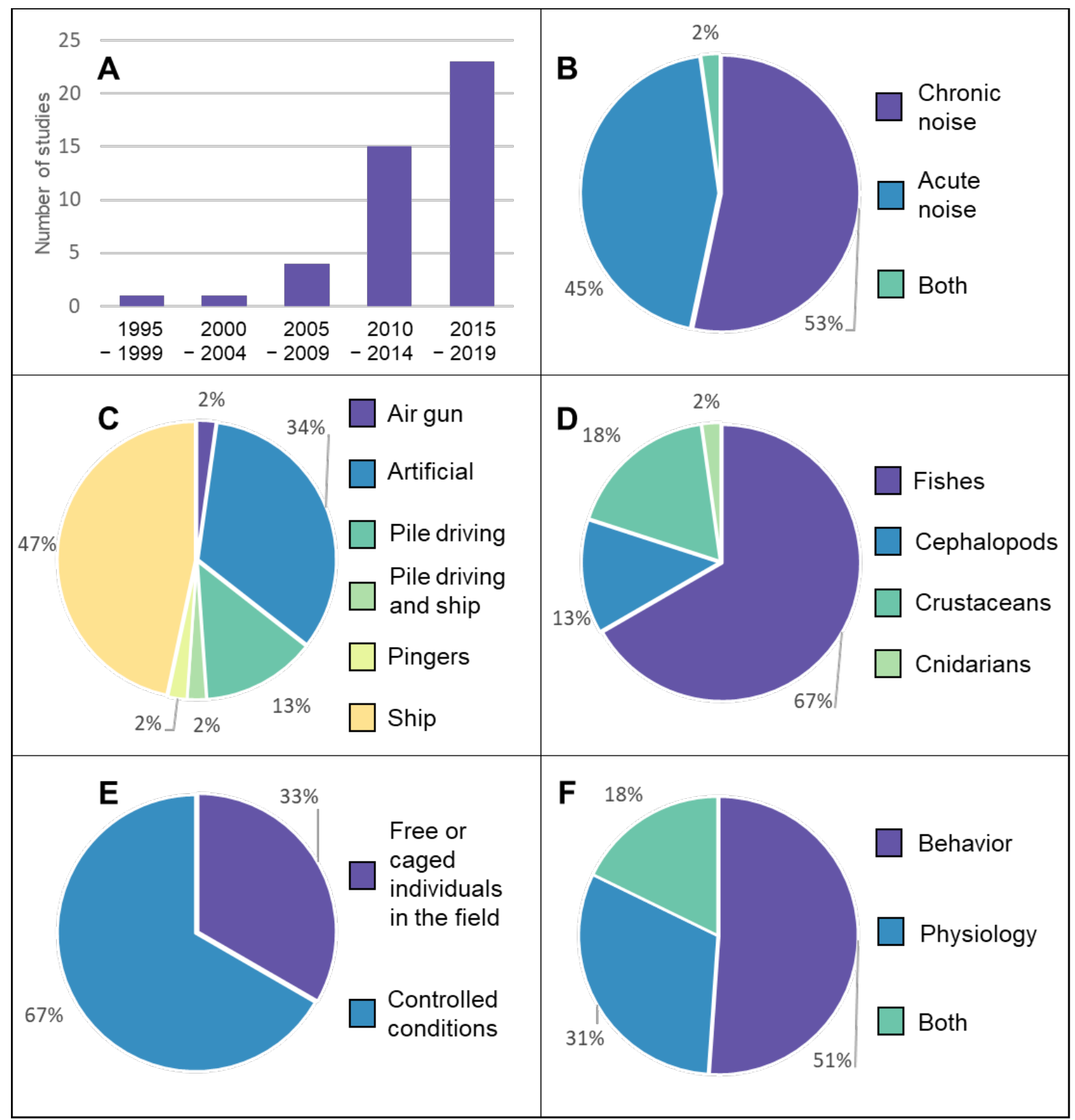

Figure 2: Summary schemes of the studies considered in this review. A) Temporal trend of published studies on the impact of noise pollution on Mediterranean fishes and invertebrates ; B) Type of noise; C) Source of noise pollution; D) Taxonomic group investigated; E) Experimental conditions; F) Category of variable considered. 
Table 1: Response variables assessed for fish studies

\begin{tabular}{|c|c|c|c|c|}
\hline \multirow[b]{2}{*}{$\begin{array}{l}\text { Noise } \\
\text { type }\end{array}$} & \multirow[b]{2}{*}{ Species } & \multicolumn{2}{|l|}{ Response variable } & \multirow[b]{2}{*}{ Reference } \\
\hline & & Behavior & Physiology & \\
\hline \multirow{16}{*}{ Acute } & Alosa alosa & Swimming speed & 1 & Wilson et al., (2008) \\
\hline & Chelon labrosus & Swimming speed and depth & 1 & Kastelein et al,. (2007) \\
\hline & \multirow{8}{*}{ Dicentrarchus labrax } & / & Primary and secondary stress response & $\begin{array}{l}\text { Debusschere et al., (2014, } \\
\text { 2016) }\end{array}$ \\
\hline & & $\begin{array}{l}\text { Fish shoal behavior (cohesion, direction, } \\
\text { coordination) }\end{array}$ & / & Herbert-Read et al., (2017) \\
\hline & & $\begin{array}{l}\text { Startle response, swimming speed and depth } \\
\text { and group cohesion }\end{array}$ & / & Neo et al., (2014) \\
\hline & & Swimming patterns & 1 & Neo et al., (2015) \\
\hline & & Swimming speed and depth & / & Neo et al., (2016) \\
\hline & & ㄴ. & Ventilation rate & Radford et al., (2016) \\
\hline & & Startle response, swimming behavior & $\begin{array}{l}\text { Cortisol, glucose, lactate, AMP, ADP, ATP and } \\
\text { cAMP }\end{array}$ & Santulli et al., (1999) \\
\hline & & Swimming speed and depth & / & Kastelein et al,. (2007) \\
\hline & Pleuronectes platessa & 1 & Oxygen uptake & Bruintjes et al., (2016) \\
\hline & Scomber scomber & Group behavior and swimming depth & 1 & Hawkins et al., (2014) \\
\hline & Solea solea & 1 & Mortality & Bolle et al., (2012) \\
\hline & $\begin{array}{l}\text { Spondyliosoma } \\
\text { cantharus }\end{array}$ & 1 & Oxygen uptake & Bruintjes et al., (2016) \\
\hline & Sprattus sprattus & Group behavior and swimming depth & 1 & Hawkins et al., (2014) \\
\hline & Trisopterus luscus & Swimming speed and depth & 1 & Kastelein et al,. (2007) \\
\hline \multirow[t]{3}{*}{ Chronic } & \multirow{2}{*}{ Anguilla anguilla } & \multirow{2}{*}{ Startle response } & \multirow{2}{*}{ Ventilation rate } & Purser et al., (2016) \\
\hline & & & & Bruintjes et al., (2016) \\
\hline & Chromis chromis & Escape duration, school density & Body condition & Bracciali et al., (2012) \\
\hline
\end{tabular}




\begin{tabular}{|c|c|c|c|}
\hline & 1 & $\begin{array}{l}\text { Glucose, lactate and total proteins in plasma as } \\
\text { well as expression of HSP } 70\end{array}$ & Vazzana et al., (2017) \\
\hline & I & Hearing thresholds & Codarin et al., (2009) \\
\hline & Nest caring behavior & 1 & Picciulin et al., (2010) \\
\hline \multirow{2}{*}{ Dicentrarchus labrax } & Predator response & Ventilation rate & Bruintjes et al., (2016) \\
\hline & Swimming behavior & Lactate, haematocrit levels and glucose & Buscaino et al., (2010) \\
\hline \multirow{3}{*}{ Gobius cruentatus } & I & Hearing thresholds & Codarin et al., (2009) \\
\hline & Territorial behavior & 1 & Sebastianutto et al., (2011) \\
\hline & Sheltering behavior & 1 & Picciulin et al., (2010) \\
\hline $\begin{array}{l}\text { Halobatrachus } \\
\text { dydactilus }\end{array}$ & Communication distance & 1 & Alves et al., (2002) \\
\hline Hippocampus guttulatus & Displacement & Respiration rate & Palma et al., (2019) \\
\hline Pomatochistus microps & Mating success & 1 & Blom et al., (2019) \\
\hline \multirow{3}{*}{ Sciaena umbra } & Flight reaction and hiding behavior & 1 & La Manna et al., (2016) \\
\hline & Fish vocalizations & 1 & Picciulin et al., (2012) \\
\hline & 1 & Hearing thresholds & Codarin et al., (2009) \\
\hline \multirow{3}{*}{ Sparus aurata } & Swimming behavior & Lactate, haematocrit levels and glucose & Buscaino et al., (2010) \\
\hline & 1 & $\begin{array}{l}\text { Weight, fork length, ACTH, cortisol, glucose, } \\
\text { lactete, haematocrit, HSP 70, cholesterol, } \\
\text { triglycerides and osmolarity }\end{array}$ & Celi et al., (2016) \\
\hline & 1 & $\begin{array}{l}\text { Total oxidant status, lysozyme activity, } \\
\text { antiprotease activity, white blood cells and } \\
\text { albumin / globulin ratio }\end{array}$ & Filiciotto et al., (2017) \\
\hline Thunnus thynnus & Swimming behavior & 1 & Sarà et al., (2007) \\
\hline
\end{tabular}


Table 2: Response variables assessed for invertebrate studies

\begin{tabular}{|c|c|c|c|c|c|}
\hline \multirow[b]{2}{*}{$\begin{array}{l}\text { Noise } \\
\text { type }\end{array}$} & \multirow[b]{2}{*}{ Group } & \multirow[b]{2}{*}{ Species } & \multicolumn{2}{|l|}{ Response variable } & \multirow[b]{2}{*}{ Reference } \\
\hline & & & Behavior & Physiology & \\
\hline \multirow{8}{*}{ Acute } & \multirow{5}{*}{ Cephalopods } & Loligo vulgaris & 1 & Statocyst lesions & $\begin{array}{l}\text { André et al., (2011); Solé et } \\
\text { al., (2013) }\end{array}$ \\
\hline & & Illex condietii & 1 & Statocyst lesions & $\begin{array}{l}\text { André et al., (2011); Solé et } \\
\text { al., (2013) }\end{array}$ \\
\hline & & Octopus vulgaris & 1 & Statocyst lesions & $\begin{array}{l}\text { André et al., (2011); Solé et } \\
\text { al., (2013) }\end{array}$ \\
\hline & & \multirow[t]{2}{*}{ Sepia officinalis } & 1 & Statocyst lesions & $\begin{array}{l}\text { André et al., (2011); Solé et } \\
\text { al., (2013); Solé et al., } \\
\text { (2017) }\end{array}$ \\
\hline & & & Inking and getting & 1 & Samson et al., (2014) \\
\hline & Crustaceans & Pagurus bernardus & $\begin{array}{l}\text { Antennas retraction, locomotion behavior, } \\
\text { shell selection }\end{array}$ & / & $\begin{array}{l}\text { Roberts et al., (2016); Walsh } \\
\text { et al., (2017) }\end{array}$ \\
\hline & \multirow{2}{*}{ Cnidarians } & $\begin{array}{l}\text { Cotylorhiza } \\
\text { tuberculata }\end{array}$ & / & Statocyst lesions & Solé et al., (2016) \\
\hline & & Rhizostoma pulmo & 1 & Statocyst lesions & Solé et al., (2016) \\
\hline \multirow{6}{*}{ Chronic } & \multirow{5}{*}{ Crustaceans } & \multirow{2}{*}{ Pagurus bernardus } & & \multirow[b]{2}{*}{ / } & $\begin{array}{l}\begin{array}{l}\text { Nousek-McGregor et al., } \\
(2016)\end{array} \\
\end{array}$ \\
\hline & & & Grouping behavior and predator response & & Tidau et al., (2016) \\
\hline & & Palaemon serratus & Locomotor patters and sheltering & $\begin{array}{l}\text { Protein concentration, DNA integrity, } \\
\text { HSPs } 27 \text { and } 70\end{array}$ & Filiciotto et al., (2016) \\
\hline & & \multirow{2}{*}{ Palinurus elephas } & 1 & $\begin{array}{l}\text { Haemocyte count, phenoloxydase } \\
\text { activity and HSP } 27\end{array}$ & Celi et al., (2015) \\
\hline & & & Locomotion activity & $\begin{array}{l}\text { Glucose, total proteins, Hsp70 } \\
\text { expression and total haematocyte count }\end{array}$ & Filiciotto et al., (2014) \\
\hline & Cephalopods & Sepia officinalis & Visual displays & 1 & Kunc et al., (2014) \\
\hline
\end{tabular}




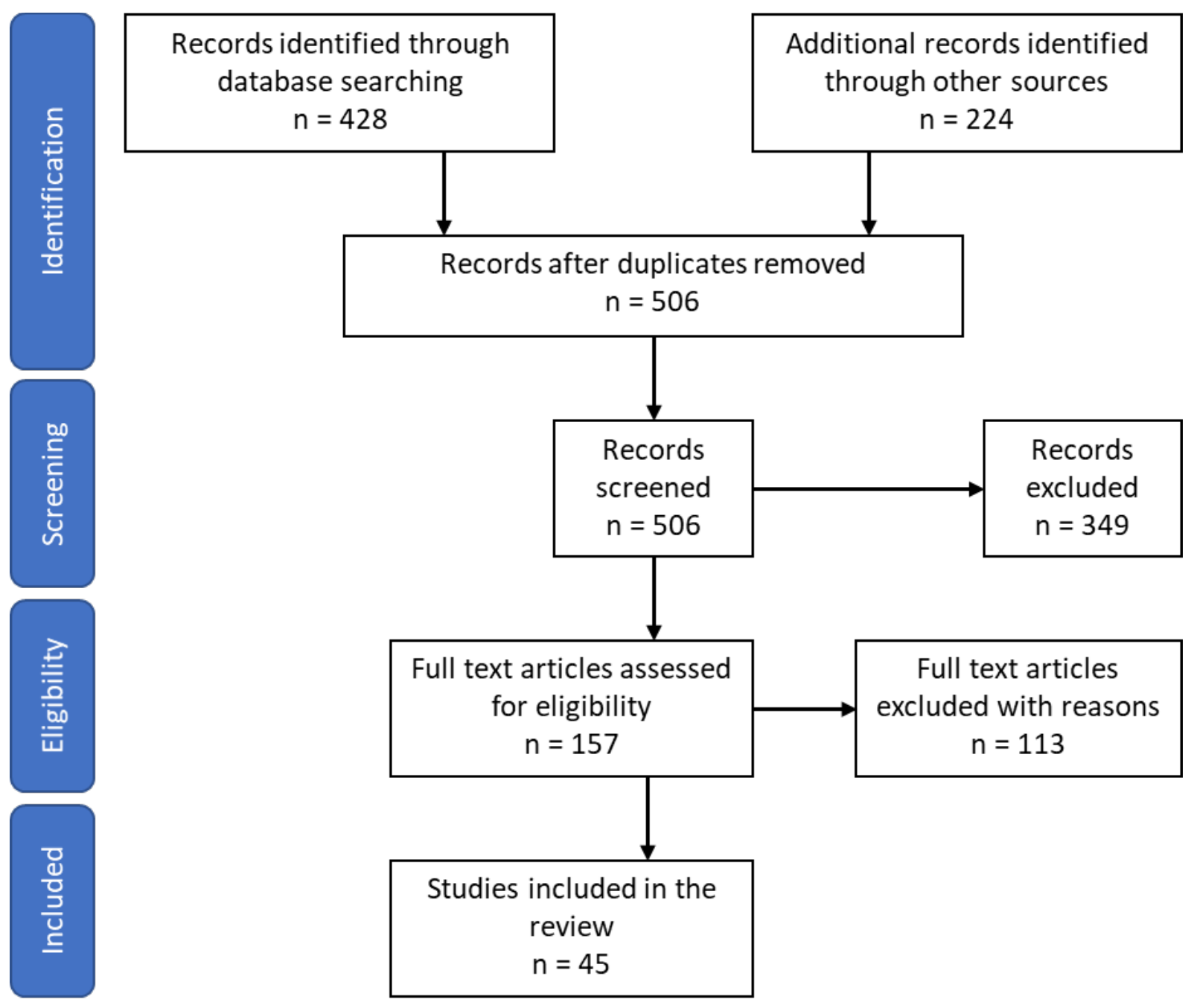

Supplementary figure 1: Flowchart of the studies selection following the PRISMA protocol. Results refer to peer-reviewed articles published in international journals between January 1990 and December 2019. 
Supplementary table 1: Summary information of the studies investigated in this review.

\begin{tabular}{|c|c|c|c|c|c|c|c|c|c|c|}
\hline Authors & Year & Group & Species & $\begin{array}{l}\text { Type of } \\
\text { noise }\end{array}$ & Source & $\begin{array}{l}\text { Level (dB re } \\
1 \mu \mathrm{Pa})\end{array}$ & $\begin{array}{l}\text { Frequency } \\
\quad(\mathrm{Hz})\end{array}$ & Duration & $\begin{array}{c}\text { Field / } \\
\text { Controlled } \\
\text { conditions }\end{array}$ & Location \\
\hline Alves et al. & 2002 & Fish & Halobatrachus dydactilus & Chronic & Ship & 130 & 1 & $1,5 \mathrm{~s}$ & Aquaria & 1 \\
\hline André et al. & 2011 & Cephalopods & $\begin{array}{l}\text { Loligo vulgaris; Sepia officinalis; } \\
\text { Octopus vulgaris; Illex coindetii }\end{array}$ & Acute & Artificial & 157 & $\begin{array}{l}50-400 \\
\text { (sweeps) }\end{array}$ & $2 \mathrm{~h}$ & Tank & / \\
\hline Blom et al. & 2019 & Fish & Pomatochistus microps & Chronic & Artificial & $\begin{array}{l}34 \mathrm{~dB} \text { higher } \\
\text { than control }\end{array}$ & I & $36 \mathrm{~h}$ & Aquaria & I \\
\hline Bolle et al. & 2012 & Fish & Solea solea & Acute & $\begin{array}{c}\text { Pile } \\
\text { Driving }\end{array}$ & $\begin{array}{c}\mathrm{SEL}_{\mathrm{cum}} 206 \\
\mathrm{~dB} \text { re } 1 \mu \mathrm{Pa}^{2} \mathrm{~s}\end{array}$ & I & 100 strikes & Aquaria & I \\
\hline Bracciali et al. & 2012 & Fish & Chromis chromis & Chronic & Ship & I & l & I & Field & $\begin{array}{l}\text { Capo Gallo, } \\
\text { Sicily, Italy }\end{array}$ \\
\hline Bruintjes et al. & 2016 & Fish & $\begin{array}{c}\text { Anguilla anguilla; Dicentrarchus } \\
\text { labrax }\end{array}$ & Chronic & Ship & $139,3-141,2$ & $50-5000$ & $2 \mathrm{~min}$ & Aquaria & I \\
\hline Bruintjes et al. & 2016 & Fish & $\begin{array}{l}\text { Spondyliosoma cantharus; } \\
\text { Pleuronectes platessa }\end{array}$ & Acute & $\begin{array}{c}\text { Pile } \\
\text { driving }\end{array}$ & $\begin{array}{c}\mathrm{SEL}_{\text {cum }} 184 \\
\mathrm{~dB} \text { re } 1 \mu \mathrm{Pa}^{2} \mathrm{~s}\end{array}$ & I & $30 \mathrm{~min}$ & Mesocosm & I \\
\hline Buscaino et al. & 2010 & Fish & $\begin{array}{c}\text { Dicentrarchus labrax; Sparus } \\
\text { aurata }\end{array}$ & Chronic & Artificial & $150 \mathrm{~dB}$ & $100-1000$ & $10 \mathrm{~min}$ & Cage & $\begin{array}{c}\text { Trapani, Sicily, } \\
\text { Italy }\end{array}$ \\
\hline Celi et al. & 2015 & Crustaceans & Palinurus elephas & Chronic & Ship & 1 & 1 & $30 \mathrm{~min}$ & Tank & 1 \\
\hline Celi et al. & 2016 & Fish & Sparus aurata & Chronic & Ship & 1 & 1 & 10 days & Tank & 1 \\
\hline Codarin et al. & 2009 & Fish & $\begin{array}{l}\text { Chromis chromis; Sciaena } \\
\text { umbra; Gobius cruentatus }\end{array}$ & Chronic & Ship & $132 \mathrm{~L}_{\text {leq, } 1 \text { min }}$ & $300-10000$ & / & Aquaria & I \\
\hline $\begin{array}{l}\text { Debusschere } \\
\text { et al. }\end{array}$ & 2014 & Fish & Dicentrarchus labrax & Acute & $\begin{array}{l}\text { Pile } \\
\text { Driving }\end{array}$ & $\begin{array}{c}\text { SEL } L_{s s} 181- \\
185 \mathrm{~dB}^{2} \\
1 \mu \mathrm{Pa}^{2} \mathrm{~s}\end{array}$ & l & $\begin{array}{l}1739 \text { to } \\
3067 \text { strikes }\end{array}$ & $\begin{array}{l}\text { Field in } \\
\text { Vials }\end{array}$ & $\begin{array}{c}\text { Lodewijckbank, } \\
\text { North Sea, } \\
\text { Belgium }\end{array}$ \\
\hline $\begin{array}{l}\text { Debusschere } \\
\text { et al. }\end{array}$ & 2016 & Fish & Dicentrarchus labrax & Acute & $\begin{array}{l}\text { Pile } \\
\text { Driving }\end{array}$ & $\begin{array}{c}\text { SEL } L_{\text {ss }} 181- \\
185 \mathrm{~dB}^{2} \text { re } \\
1 \mu \mathrm{Pa}^{2} \mathrm{~s}\end{array}$ & / & $1,5 \mathrm{~h}$ & $\begin{array}{l}\text { Field in } \\
\text { Vials }\end{array}$ & $\begin{array}{c}\text { Lodewijckbank, } \\
\text { North Sea, } \\
\text { Belgium }\end{array}$ \\
\hline Filiciotto et al. & 2014 & Crustaceans & Palinurus elephas & Chronic & Ship & 1 & I & $30 \mathrm{~min}$ & Tank & I \\
\hline Filiciotto et al. & 2016 & Crustaceans & Palaemon serratus & Chronic & Ship & 1 & $100-3000$ & $31 \mathrm{~min}$ & Tank & I \\
\hline Filiciotto et al. & 2017 & Fish & Sparus aurata & Chronic & Ship & $112-131$ & $25-1000$ & 40 days & Tank & 1 \\
\hline $\begin{array}{c}\text { González } \\
\text { Correa et al. }\end{array}$ & 2019 & Fish & Assemblage & Chronic & Ship & l & I & l & Field & $\begin{array}{c}\text { Tabarca / Ibizia / } \\
\text { Formentera, }\end{array}$ \\
\hline
\end{tabular}




\begin{tabular}{|c|c|c|c|c|c|c|c|c|c|c|}
\hline & & & & & & & & & & Spain \\
\hline Hawkins et al. & 2014 & Fish & $\begin{array}{c}\text { Sparattus sprattus; Scomber } \\
\text { scombrus }\end{array}$ & Acute & $\begin{array}{l}\text { Pile } \\
\text { Driving }\end{array}$ & $\begin{array}{l}\text { 163,2 peak- } \\
\text { to-peak }\end{array}$ & $50-600$ & I & Field & $\begin{array}{l}\text { Lough Hyne, } \\
\text { County Cork, } \\
\text { Ireland }\end{array}$ \\
\hline $\begin{array}{l}\text { Herbert-Read } \\
\text { et al. }\end{array}$ & 2017 & Fish & Dicentrarchus labrax & Acute & $\begin{array}{c}\text { Pile } \\
\text { Driving }\end{array}$ & / & / & $5 \mathrm{~min}$ & Aquaria & I \\
\hline $\begin{array}{l}\text { Kastelein et } \\
\text { al. }\end{array}$ & 2007 & Fish & $\begin{array}{c}\text { Dicentrarchus labrax; Trisopterus } \\
\text { luscus; Chelon labrosus }\end{array}$ & Acute & Pingers & $\begin{array}{c}\text { Pinger } \\
\text { dependent }\end{array}$ & $\begin{array}{c}\text { Pinger } \\
\text { dependent }\end{array}$ & $0,3 \mathrm{~s}$ & Tank & I \\
\hline Kunc et al. & 2014 & Cephalopods & Sepia officinalis & Chronic & Ship & 1 & 1 & $210 s$ & Tank & 1 \\
\hline $\begin{array}{l}\text { La Manna et } \\
\text { al. }\end{array}$ & 2016 & Fish & Sciaena umbra & Chronic & Ship & $\begin{array}{l}\text { Mean: } 134 \\
\text {-146; Max: } \\
\text { 145 -154 }\end{array}$ & / & I & Field & $\begin{array}{l}\text { Porto Conte, } \\
\text { Sardinia, Italy }\end{array}$ \\
\hline Neo et al. & 2014 & Fish & Dicentrarchus labrax & Acute & Artificial & $134-172$ & 1 & $30 \mathrm{~min}$ & Tank & 1 \\
\hline Neo et al. & 2015 & Fish & Dicentrarchus labrax & Acute & Artificial & $158 \mathrm{SPL}_{\mathrm{z}-\mathrm{p}}$ & $200-1000$ & $\begin{array}{l}900-7200 \\
\text { pulses }\end{array}$ & Tank & I \\
\hline Neo et al. & 2016 & Fish & Dicentrarchus labrax & Acute & Artificial & 80-192 SPL $L_{z-p}$ & $200-1000$ & $60 \mathrm{~min}$ & Cage & $\begin{array}{c}\text { Jacobahaven, } \\
\text { Oosterschelde, } \\
\text { Netherlands }\end{array}$ \\
\hline $\begin{array}{c}\text { Nousek- } \\
\text { McGregor and } \\
\text { Mei }\end{array}$ & 2016 & Crustaceans & Pagurus bernardus & Chronic & Ship & $50-58$ & $1000-3000$ & / & Aquaria & I \\
\hline Palma et al. & 2019 & Fish & Hippocampus guttulatus & Chronic & Ship & $\begin{array}{c}\text { Transient: } \\
\text { 63,4-127,6 } \\
\text { Constant: } \\
137,1 \\
\end{array}$ & I & I & Field & $\begin{array}{c}\text { Ria Formosa } \\
\text { lagoon, south } \\
\text { Portugal }\end{array}$ \\
\hline Picciulin et al. & 2010 & Fish & Gobius cruentatus; Chromis chromis & Chronic & Ship & $\begin{array}{c}140,3-158,8 \\
\mathrm{~L}_{\text {leq,25s }} 147,7- \\
162,2\end{array}$ & / & $5 \mathrm{~min}$ & Field & $\begin{array}{c}\text { WWF-Miramare } \\
\text { Natural Marine } \\
\text { Reserve, Gulf of } \\
\text { Triste, Italy } \\
\end{array}$ \\
\hline Picciulin et al. & 2012 & Fish & Sciaena umbra & Chronic & Ship & $\begin{array}{c}133-135 \\
\text { Lleq, } 1 \min 144-_{150}\end{array}$ & I & / & Field & $\begin{array}{c}\text { WWF-Miramare } \\
\text { Natural Marine } \\
\text { Reserve, Gulf of } \\
\text { Triste, Italy } \\
\end{array}$ \\
\hline Purser et al. & 2016 & Fish & Anguilla anguilla & Chronic & Ship & 148 & 1 & $2 \mathrm{~min}$ & Aquaria & I \\
\hline Radford et al. & 2016 & Fish & Dicentrarchus labrax & Acute / & Pile & 146 / 124 & I & 1 & Aquaria & I \\
\hline
\end{tabular}




\begin{tabular}{|c|c|c|c|c|c|c|c|c|c|c|}
\hline & & & & Chronic & $\begin{array}{l}\text { driving / } \\
\text { Ship }\end{array}$ & & & & & \\
\hline Roberts et al. & 2016 & Crustaceans & Pagurus bernardus & Acute & Artificial & 1 & $5-410$ & 1 & Aquaria & 1 \\
\hline Samson et al. & 2014 & Cephalopods & Sepia officinalis & Acute & Artificial & $85-188$ & $80-1000$ & $3 \mathrm{~s}$ & Tank & 1 \\
\hline Santulli et al. & 1999 & Fish & Dicentrarchus labrax & Acute & Air gun & I & I & I & Field & $\begin{array}{c}\text { Adriatic Sea off } \\
\text { the coast of } \\
\text { Ancona, Italy }\end{array}$ \\
\hline Sarà et al. & 2007 & Fish & Thunnus thynnus & Chronic & Ship & up to 135 & I & I & Cage & $\begin{array}{l}\text { Favignana, } \\
\text { Sicily, Italy }\end{array}$ \\
\hline $\begin{array}{l}\text { Sebastianutto } \\
\text { et al. }\end{array}$ & 2011 & Fish & Gobius cruentatus & Chronic & Ship & $\begin{array}{c}\begin{array}{c}162.2 \mathrm{~L}_{\text {leq }}, 1 \\
\min \end{array} \\
\end{array}$ & / & I & Aquaria & / \\
\hline Solé et al. & 2013 & Cephalopods & $\begin{array}{l}\text { Sepia officinalis; Octopus vulgaris; } \\
\text { Loligo vulgaris; Illex condietii }\end{array}$ & Acute & Artificial & up to 175 & $\begin{array}{c}50-400 \\
\text { sweeps }\end{array}$ & $2 \mathrm{~h}$ & Tank & I \\
\hline Solé et al. & 2013 & Cephalopods & Loligo vulgaris; Illex condietii & Acute & Artificial & up to 175 & $\begin{array}{l}50-400 \\
\text { sweeps }\end{array}$ & $2 \mathrm{~h}$ & Tank & I \\
\hline Solé et al. & 2016 & Cnidarians & $\begin{array}{l}\text { Cotylorhiza tuberculata; Rhizostoma } \\
\text { pulmo }\end{array}$ & Acute & Artificial & up to 175 & $\begin{array}{l}50-400 \\
\text { sweeps }\end{array}$ & $2 \mathrm{~h}$ & Aquaria & l \\
\hline Solé et al. & 2017 & Cephalopods & Sepia officinalis & Acute & Artificial & 139-142 & $\begin{array}{c}100-400 \\
\text { sweeps }\end{array}$ & $2 \mathrm{~h}$ & Field & $\begin{array}{l}\text { Catalan coast, } \\
\text { Spain } \\
\end{array}$ \\
\hline $\begin{array}{l}\text { Tidau and } \\
\text { Briffa }\end{array}$ & 2019 & Crustaceans & Pagurus bernardus & Chronic & Ship & 119.4 & I & $2 \min$ & Aquaria & I \\
\hline $\begin{array}{c}\text { Tidau and } \\
\text { Briffa }\end{array}$ & 2019 & Crustaceans & Pagurus bernardus & Chronic & Ship & 119.4 & / & $2 \min$ & Aquaria & I \\
\hline Vazzana et al. & 2017 & Fish & Chromis chromis & Chronic & Artificial & $127-130$ & $200-300$ & $2 \min$ & Aquaria & 1 \\
\hline Walsh et al. & 2017 & Crustaceans & Pagurus bernardus & Acute & Artificial & 165 & up to 2000 & $30 \mathrm{~min}$ & Aquaria & I \\
\hline Wilson et al. & 2008 & Fish & Alosa alosa & Acute & Artificial & 161-167 & $\begin{array}{l}10000- \\
120000\end{array}$ & I & Tank & I \\
\hline
\end{tabular}

